\title{
The legal and regulatory framework for the EU' shale gas exploration and production regulating public health and environmental impacts
}

\author{
Joseph Tawonezvi ${ }^{1}$ (D) \\ ${ }^{1}$ Law Department, Robert Gordon University, Aberdeen, Aberdeenshire, UK
}

Received: 13 May 2016/Revised: 8 September 2016/Accepted: 11 October 2016/Published online: 1 November 2016

(c) The Author(s) 2016. This article is published with open access at Springerlink.com

\begin{abstract}
Shale gas has now become a major competing source of energy in the international energy mix scenario. In the European Union, the "fracking" which is the technique of extraction shale gas is facing very strong opposition based on the associated potential health risks and environmental impacts which are not currently adequately regulated. The European Union Commission argues that the current regulatory system is enough for controlling the impacts of fracking on health and the environment. However, this article shows that the EU shale gas regulatory framework is not, "fit for purpose". It will critically evaluate current European Union shale gas regulations and offer some recommendations for improvement.
\end{abstract}

$\begin{array}{ll}\text { Abbreviations } \\ \text { ADR } & \text { Treaty of the European Union } \\ \text { BAT } & \text { Best available techniques } \\ \text { BCM } & \text { Billion cubic metres } \\ \text { CEU } & \text { Council of the European Union } \\ \text { CR } & \text { Commission recommendation } \\ \text { DG } & \text { Directorate General } \\ \text { EAP } & \text { Environmental Action Programme } \\ \text { EC } & \text { European Commission } \\ \text { ECHA } & \text { European Chemical Agency } \\ \text { ECJ } & \text { European Court of Justice } \\ \text { EIA } & \text { Energy Information Administration } \\ \text { EIA } & \text { Environmental Impact Assessment } \\ \text { EP } & \text { European Parliament } \\ \text { EP } & \text { Exploration and production } \\ \text { EU } & \text { European Union }\end{array}$

FOEE Friends of the Earth Europe

FPIC Free, Prior and Informed Consent

HVHF High-volume hydraulic fracturing

IEA International Energy Agency

IOGP International Association of Oil and Gas

Producers

MS Member States

NGO Non-governmental organisations

NGPL Natural gas plant liquids

NIMBY Not-in-my-backyard factor

PSNR Permanent Sovereignty over Natural Resources

REACH Registration, Evaluation, Authorisation and Restriction of chemicals

REC Reduced emission completions

SAC Special areas of conservation

SEA Strategic environment assessment

SG Shale gas

SGEP Shale gas exploration and production

TCF Trillion cubic feet

TEU Alternative dispute resolution

TFEU Treaty on the Functioning of the European Union

UNECE United Nations Economic Commission for Europe

UNESCO United Nations Educational Scientific and Cultural Organisation

UNGA United Nations General Assembly

USA United States of America 


\section{Introduction}

The objective of this paper is to analyse whether the European Union (EU) shale gas regulations are fit for purpose and able to protect the environment and human health against the effects of shale gas activities. A background of the shale gas technical features and environmental potential impacts is necessary to have an understanding of what is involved in high-volume hydraulic fracturing (HVHF) processes and the potential impacts to enable an assessment of the regulations that are applied in minimising or preventing environmental damages in the EU.

In analysing the current regulatory framework for the shale gas fracking activities in the EU, it was necessary to review the EU primary legislation on shale gas industry, the legal principles influencing the legislation and the composition EU legislative bodies and their roles and the efforts the EU has been so far putting in terms of improving the regulations relating to shale gas exploration and production.

An analysis of secondary legislation relevant in permitting and operational fracking activities in the EU is also important in assessing the effectiveness and weaknesses of various provisions that regulate the potential impacts likely to cause serious environmental damage and health impacts. The environmental regulatory management systems and applications of EU member states pursuing shale gas activities will also be analysed. These reviews and analysis form the bases of the conclusions and recommendations that may contribute to the improvement of regulatory weaknesses identified.

\subsection{The Background}

The exploration and production (EP) involving hydraulic fracturing is currently for hydrocarbons that are unconventional including gas deposits. There is intensive public discussion going on in the European Union (EU) focusing on the potential environmental and health effects that can be brought about by carrying shale gas extraction by fracking. Shale gas extraction has become a controversial and very competitive resource in the energy mix worldwide. The United States of America (USA) is now advanced on commercial production and already reaping large economic benefits which inter alia includes the expansion of natural gas plant liquids (NGPL), manufacturing chemical, primary metals and replacing the petroleum-based naphtha7 feedstocks with increased use of NGPL feedstocks. ${ }^{1}$

$\overline{1 \text { EIA (2015). }}$
There is need for authorities and operators to abide by the regulations that are related to permitting and operational activities of shale gas exploration and production aimed at preventing or minimising environmental and human health impacts.

\subsection{Shale gas potential in the European Union (EU)}

In 2013, an estimation of 885 trillion cubic feet (tcf) of shale gas could be recovered in Europe, representing about $12 \%$ of worldwide shale gas potential from all European countries by the end of 2012. ${ }^{2}$ Fourteen European countries are believed to have shale gas resources present in their territories of which largest resources are found in France and Poland. Other states such as Norway, Ukraine, Sweden, Denmark and the United Kingdom (UK) have also large deposits. The EU is the largest world regional market for gas demand estimated at 550 billion cubic metres $(\mathrm{BCM})$ in 2010, which is on the increase whilst production is decreasing in the region. ${ }^{3}$ Unconventional gas production in the EU is expected to grow at a much slower rate from $10 \mathrm{BCM}$ in 2010 and expected to grow much quicker to $80 \mathrm{BCM}$ by $2035 .^{4}$

At the moment, there is no law specifically for regulating SG activities other than various EU provisions that were enacted for regulating the environmental issues and mining activities in the EU. ${ }^{5}$

The big question is whether these unspecific but, "catch all", ${ }^{6}$ directives effective enough to help gain "social licence to operate", and win against a growing numbers successful anti-fracking campaigns in the EU? This question will be fully answered by the end of this article.

The USA so far dominates the shale gas production resources and expected to become an overall net exporter of natural gas by 2017 and a net pipeline exporter of natural gas in $2018 .^{7}$ The gas prices are much lower in the USA as compared to the European prices.

The production of shale gas in the EU is expected to bring some of these benefits which the USA is currently enjoying. It will bring economic and energy security benefits as well as reducing aggregate gas supplies from other countries such as Russia where the supply chain can be volatile. Those who are pro-shale gas activities argue that the use of more gas helps to reduce carbon emission by replacing more carbon intense fuels and be in a position to achieve the greenhouse targets whilst some regard it as

\footnotetext{
${ }^{2}$ EIA (2013).

3 IEA (2012).

${ }^{4}$ See supra footnote.

5 Reins (2011).

${ }^{6}$ Dinan (1999).

7 See supra footnote 1 .
} 
unreliable accelerator of zero-carbon society facilitating acceleration of climate change. ${ }^{8}$

A number of potential technical and environmental concerns on the shale gas production have been so far identified, which includes water contamination, air pollution, ecological damage, noise pollution and harmful environmental pollution caused by the release of chemicals. These issues require a strong and reliable regulatory capacity covering shale gas extraction and protect health and environmental risks. ${ }^{9}$ The risks related to shale gas exploitation demand a regulatory regime at the European level based on the, "precautionary principle".

However, in 2011 the Directorate General (DG) for the Energy of the European Commission (EC) reported that the environmental legislation in the $\mathrm{EU}$ is also applicable at every stage of shale gas activities. This prompted the initiation of a number of studies covering different aspects of shale gas activities relating to shale gas economics, methane emissions and the adequacy of regulatory framework to ensure the environment and human health are protected from the impacts caused by shale gas production. The European Parliament also debated on the shale gas's current regulatory framework's various defects. ${ }^{10}$

\subsection{Research methods}

Qualitative approaches to this research shall be utilised throughout the research and collecting empirical data EU law treaties, directives, regulations, general principles and European Court of Justice (ECJ) decisions on environmental issues related to shale gas extraction.

The literature shall be briefly analysed below and reviewed throughout the article, in defining and analysing the EU legislative process, its legislative institutions and control of legislation on shale gas extraction activities in the EU and its Member States (MS). The literature will be used to understand the impacts caused by shale gas exploration and production, the effectiveness of regulations on the environmental these impacts. The response and application of the EU regulations by its MS will also be analysed.

In order to achieve this, various sources will be analysed which includes textbooks, academic research journals and articles, oil and gas industry journals, academic writings and the official EU journal EU commission. Parliament reports on shale gas policy matters and the European Environmental news information will be searched for any latest environmental issues. The United States literature which contains more detailed experiences from the shale

\footnotetext{
${ }^{8}$ FOEE (2015).

9 European Parliament 2011/2308(INI) (2012).

${ }^{10}$ See supra footnote 3 .
}

gas activities for many years will also be looked into. Reports from the Energy Information Administration (EIA, the International Environmental Agency (IEA) and Friends of the Earth (FOE) will be used in analysing the EU shale gas environmental regulatory regime.

The ECJ plays a very important role in interpreting legislations provisions applicable to shale gas extraction and making decisions on breaches of the environmental regulations in the EU; therefore, a number of decided cases and matters referred by domestic MS for guidance will be analysed. ${ }^{11}$ These cases are of importance in understanding the role played by the EU judicial system in regulating shale gas activities and to understand how the ECJ interprets EU environmental laws and how they are applied in deciding on shale gas cases and referrals from EU MS.

\subsection{Literature review}

Fracking is being encouraged by energy demand worldwide becoming a challenge to policy makers and the politicians in making environmental regulation decisions. Despite the fact that shale development in Europe is at its infancy, it is already facing a very strong opposition. The production of shale gas at this level could impact on climate change as warned by many international agencies including the $\mathrm{IPCC}^{12}$ and the International Energy Agency. ${ }^{13}$

The ever increasing fracking opposition makes it difficult to obtain for a social licence to operate, which was described by Moffat and Zhang as, "A set of meaningful relationships between shareholders based on mutual trust" 14 To have trust is to have confidence that the behaviour of an operator will match expectations of the trust holder. ${ }^{15}$

It has been suggested that a temporal moratorium is necessary in order to get the space to thoroughly scrutinise the uncertainties of the current regulatory framework and gaps, thereby giving more protection to the environment as well as public health. ${ }^{16}$

It is the task of the policy makers to determine if shale gas activities should be carried out in their respective jurisdictions. Many studies have shown that shale gas extraction causes a number of air and water health associated diseases and there are no conclusive reports as to the

\footnotetext{
11 Van Hoecke (2011).

12 http://www.climatechange2013.org/f.

${ }^{13}$ http://www.worldenergyoutlook.org/media/weowebsite/2012/gold enrules/weo2012_goldenrulesreport.pdf.

${ }^{14}$ Moffat and Zhang (2014).

15 Thomson and Boutilier (2011).

${ }^{16}$ Hawkins (2015).
} 
impacts caused by chemicals used in fracking due to nondisclosure agreements. ${ }^{17}$

The need for more studies on to the potential impacts of fracking cannot be over emphasised. Another study revealed that humans, food, domesticated and wildlife die from respiratory and growth problems due to exposure to drilling and fracturing activities. ${ }^{18}$

The biggest problem is to carry out an accurate assessment of the risks posed to on people who leave near shale gas drilling sites due to the inadequacy of current emission data collection and analysis methods. ${ }^{19}$

Studies are carried out around the world in different geologies, geography under different regulatory regimes, engineering technologies and methodologies in each study coming up with various results making difficult to reach a consensus. However, all these studies point to the fact that there are known shale gas public health risks which policy makers should take into account when considering shale gas development policies in their respective territories. ${ }^{20}$

There is lack of specific regulatory policy for shale gas extraction in the European Union and each member state put its own regulatory policies because the European Union cannot set up policies which affect member states' rights to choose and exploit any choice of energy within their sovereign states. $^{21}$

It is therefore the decision for each member state which has authority of issuing permits and authorising shale gas activities it its territory. There is no centralised Europe Union institution controlling these procedures across all member states.

Each state has the responsibility to take into account all public health and environmental considerations in making permitting and authorisation decisions. The lack of harmonised regulatory regime results in different EU regulatory interpretations among its member states. ${ }^{22}$

The European Commission has a duty of strategizing enforcement of environmental regulation, making sure there is effective monitoring compliancy which is its responsibility under Art. 211 of the EC Treaty. ${ }^{23}$ However, as shall be seen from this paper there are serious shortfalls in monitoring compliancy in the EU shale gas industry.

\footnotetext{
17 Bamberger and Oswald (2012).

18 Bamberger and Oswald (2015).

19 Brown et al. (2014).

20 Brown et al. (2015).

21 Horia Maican (2013).

22 Fleming (2015).

${ }^{23}$ Ballesteros (2009).
}

\section{The shale gas exploration and production potential environmental impacts}

Shale gas has its distinct features from other fossil fuels. It has been there for many years unexploited, but due to technological advancement, it commercial production has been made possible. The peculiar methods and techniques used to extract shale gas generate its own environmental and health impacts which needs to be addressed as the project progresses.

\subsection{What is shale gas?}

Shale gas is natural gas with a composition of methane as the main ingredient, which is a found trapped in the source rock which it was formed originally ${ }^{24}$ with very fine grains, of very low permeability which makes it difficult to be extracted and its extension can be as large as half of France. ${ }^{25}$ It is said to be unconventional because the resource has to be stimulated to enable hydrocarbons to flow due to low permeability, by injecting water at a high pressure to push gas from the rock shale. It is different from the conventional gas which flows into a conventionally drilled well without stimulation giving in large quantities of economic gas. ${ }^{26}$

Horizontal drilling and high-volume hydraulic fracturing (HVHF) are the two advanced technological processes that are used in extracting gas from its shale. Drilling using these techniques can drill a 2-km-deep well and $3 \mathrm{~km}$ or more horizontally. ${ }^{27}$ These techniques have been extensively used over the last 60 years and known as fracking or hydraulic fracturing. Other types of unconventional gas are tight gas and coalbed methane, aka coal seam gas. ${ }^{28}$ These advanced technologies have made it possible to extract shale gas in large quantities. ${ }^{29}$

Natural gas combustion releases lower levels of carbon dioxide as well as $\left(\mathrm{CO}_{2}\right)$ and sulphur dioxide than other hydrocarbons such as oil and coal. When used in efficient combined cycle power plants, natural gas combustion can emit less than half as much $\mathrm{CO}_{2}$ as coal combustion, per unit of electricity output. ${ }^{30}$ However, SG extraction has its own technical and environmental impacts. There are currently controversies surrounding the shale gas extraction development in the EU, some advocating for a moratorium because of its negative impacts on human health and

\footnotetext{
${ }^{24}$ Meiners et al. (2013).

25 Charlez (2015).

${ }^{26}$ Luscombe and Corden (2015).

27 Potocnik (2012).

${ }^{28}$ Exxon Mobil (2014).

29 Wang et al. (2014).

${ }^{30}$ See supra footnote 27 .
} 
environment whilst others see it as a means to boost their nations' energy mix, cheaper and a secure energy source supply.

\subsubsection{Issues surrounding shale gas extraction}

Shale gas exploration and production has got technical and environmental issues that has to be seriously looked into for a shale gas project to take off. It is a unique and requires very technical procedure which need a lot of expertise and done in a way that is environmental friendly. Some of them cannot be avoided with the technology and scientific knowledge currently existing and the risks to the environmental and health can happen if the process of extraction is not properly managed.

\subsubsection{What are the technical risks of shale gas production?}

The production of SG cycle takes five stages starting from identifying the suitable site and preparation, thereby triggering potential environmental and health issues. The first stage involves levelling and clearing the required area of land for the well site. There will be transportation of heavy equipment to the site and construction of storage facilities. ${ }^{31}$

The second stage will involve well designing, drilling, cementing and perforation of a hole on the surface and laying pipes, cementing and constructing the wellhead. ${ }^{32}$

The third stage is the technical hydraulic fracturing, by pumping highly pressurised water mixed with sand or other propane and chemicals. Then the well reaches a completion stage where water produced and flowback has to be managed by the operator. Production will then commence and after the well has reached its end it will then need to be decommissioned. ${ }^{33}$

However, all these stages have their peculiar environmental impacts that can start at each stage or can be accumulative from start to finish or through multiple well projects. It is the objective of the EU that individual states are obliged to make laws that regulates the potential environmental impacts on shale gas on all projects they authorise to operate in their States.

There are technical rules and regulations that operators are obliged to comply with throughout the shale gas production processes. The MS through their competent authorities are compelled to monitor the activities of the licences in their jurisdictions and to make sure they are complying with the minimum standards expected in these types of projects.

\footnotetext{
31 Dupont (2013).

32 ibid.

${ }^{33}$ ibid.
}

\subsection{The application of the best available techniques (BAT)}

"BAT" is the most available advanced and effective way of operation which is suitable for limiting pollution in cases where it is generally difficult to reduce emission and the environmental impacts. Achieving the best results in protecting the environment needs the use of advanced technology which is economic and accessible.

The BAT needs to be applied in well construction to make sure that there are no leakages of chemicals from the well into the underground aquifer or land. However, the risks cannot be ruled out completely because there are always chances of human error or technical faults which can also result even where the BAT has been applied. MS have the responsibility of making sure that operators are complying and are up to date with the most relevant information through industrial exchange from across the EU MS and further.

Sources of such information can range from non-governmental organisations that are involved in the promotion of protecting the environmental. Operators need to put in place management systems for water, transport, gas capturing, pressure management, well management and many others which need be attended to at every stage of the operation. ${ }^{34}$ The only problem is that SG is in its early development stage in the EU and the BAT is also just emerging and not yet fully integrated, thereby lacking a coherent approach of implementing a practice that is recognised across EM MS. ${ }^{35}$

Figure 1 illustrates the risks caused to air, water and land by hydraulic fracturing. The diagram shows how a horizontal drilling shale gas well is set up and how it invades the natural environment from the top soil to the passing through the water table, the impermeable rock down to the shale where the fracking takes place in order to release the gas. The diagram also shows the potential locations of the sources of water pollution. The well has to be well cemented to make sure there will be no leaks of methane or hydraulic fluids into the water or soil.

Figure 1 shows how the potential impacts of shale gas production on the environment. The drilling of the well passes through the fresh water aquifers where drinking water is drawn. The well integrity is important to make sure that it does not leak and hydraulic fluids during the time of production and after the decommissioning of the well. Some fugitive gases can also escape from the well to the atmosphere, polluting the air affecting human health

\footnotetext{
$\overline{34}$ Commission Recommendation, January 2014, on minimum principles for the exploration and production of hydrocarbons (such as shale gas) using high-volume hydraulic fracturing (2014/70/EU).

${ }^{35}$ EC (2015).
} 
Fig. 1 Shale gas production techniques and potential environmental impacts. Source Aldhous (2012)

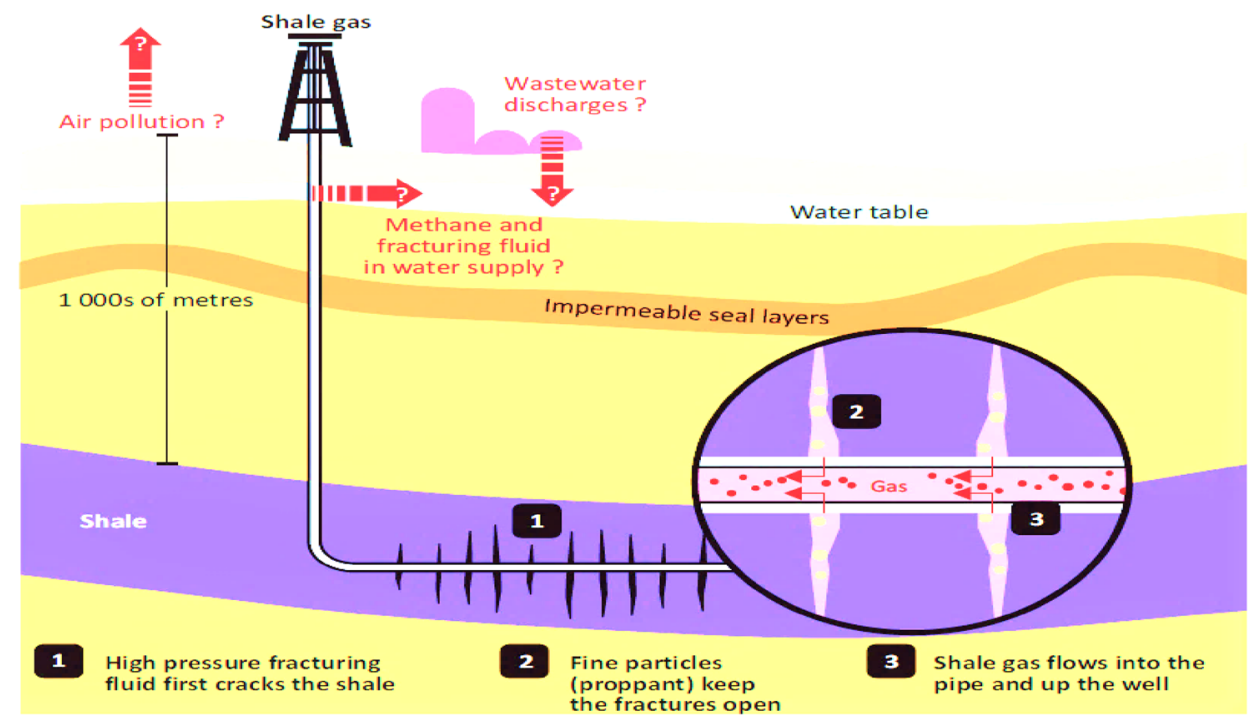

and the environment. The water discharged from the shale gas production can also contaminate the fresh water and soil. Human errors and technical faults or earth movement can be a cause for these leaks.

\subsection{What are the environmental impacts of shale gas production}

Generally, risks to the water environment, ecology and of climate change have been identified as three main categories of key potential environmental impacts of shale gas EP calling for comprehensive risk factors (RFs) that deal with such impacts. ${ }^{36}$

Hydraulic fracturing (HVHF) has serious impacts on land take due to its installations which take about $60 \%$ more than a conventional well space of a well pad. Storage tanks for water, chemicals and wastewater that can contain about $30,000 \mathrm{~m}^{3}$ and shale gas formations take up tens of thousands of square kilometres of concessions covering as large as up to $6000 \mathrm{~km}^{2}$. This makes the physical footprint associated with SG EP to be more than conventional resources extraction requirements. Access to land and land usage are likely to be important issues in densely populated EU countries and raises a lot of public support issues in shale gas projects.

HVHF requires a high demand of fresh water competing with other domestic and other industrial needs, depending with location of the project. Wastewater in large amount leads to groundwater contamination if not carefully disposed. The whole operation leaves footprints from increased truck traffic and noise, pollutants and demand in land use for setting up the infrastructure for the projects. Animals, plants and humans in the environment around

$\overline{36}$ Moore et al. (2014). extraction sites are put at risk of migration or possible extinction from all potential impacts such as land take, noise from traffic and site machinery, the visual impact of the environment and the increasing risk to of seismic events around the extraction area. ${ }^{37}$

Risks associated with shale gas exploration and production using the HVHF technical methods are found at every stage of the prospection, exploration, production until closing down of the well. Ground preparation which is identified as a suitable to set up the drilling pads causes a lot of environmental disturbances. These are not going to be discussed in detail since this article's main focus is on whether these impacts are regulated effectively by the EU legislation.

\subsubsection{The risk of water contamination}

The most feared HVHF impacts are the potential risk of water contamination and depletion. This process uses a lot of water which may affect the water supply from the surrounding natural water resources or from local supply also used by the local community. Hydraulic fracturing fluid may contain potentially hazardous chemicals which may contaminate surrounding areas through spillages and leaks. Large amounts of wastewater produced by fracturing contain dissolved chemicals and need to be treated before reused or disposed. ${ }^{38}$ Under the UK law, the environmental regulator has the power under the Water Resources Act 1991 to require shale gas developers to disclose the composition of fracturing fluids they use in their projects. ${ }^{39}$ There are also technical standards set up in the oil and gas

\footnotetext{
37 EIA Natural Gas from Shale (2013).

38 Energy Information Administration (EIA) (2012).

39 Royal Society and the Royal Academy of Engineering (2012).
} 
industry which has to be followed in shale gas activities, namely ISO $10426-1^{40}$ which covers well cementing, ISO10405 for casings ${ }^{41}$ and ISO $11961^{42}$ for Drill pipes.

\subsubsection{Induced seismicity}

Instances of earthquakes have been linked to unconventional shale gas production, for example the Cuadrilla shale gas operations near Blackpool in the UK in 2011 where a small magnitude of around two on the Richter scale was reported but did not create any surface damage. ${ }^{43}$ Hydraulic fracturing operations at Cuadrilla did not lead to a moratorium to more safety by the use of micro-seismic monitoring. ${ }^{44}$ Operators are required to implement a "traffic light" to identify unusual seismic activities that may require them to stop activities pending reassessment of operation due to hydraulic fracturing. ${ }^{45}$

\subsubsection{Greenhouse gas emissions}

SG uses higher production equipment that emits greenhouse gas emissions more than conventional gas because hydraulic fracturing need more wells to maximise production due to complex nature of its production. An operation of more wells means more diesel pumps are required thereby increasing the $\mathrm{CO}_{2}$ emitted per unit of energy. ${ }^{46}$ Gas is commonly released into the atmosphere or to flare, thereby converting methane to carbon dioxide, which is also a greenhouse gas. There is now an increasing use of reduced emission completions (REC) technologies to capture the emerging gas emissions. ${ }^{47}$

\subsubsection{Ecological impacts}

The physical footprint associated with SG EP considering the number of wells that might be required, space for transport, wastewater storage facilities and containers is quite significant as compared to that of a conventional gas project. Construction of infrastructure and production activities result in the fragmentation of environmental natural habitat lost or totally destroyed especially in some of the UK onshore gas licensing that are in some special areas of conservation (SACs) or other protected category

\footnotetext{
${ }^{40}$ Petroleum and Natural Gas Industries (2009).

${ }^{41}$ Petroleum and Natural Gas Industries (2006).

42 Petroleum and Natural Gas Industries (2011).

${ }^{43}$ See supra footnote 8 .

${ }^{44}$ Green et al. (2012).

${ }^{45}$ See supra footnote 31.

${ }^{46}$ See supra footnote 44.

47 EPA (2011).
}

special areas, ${ }^{48}$ and also in Poland where Chevron was licensed to explore shale gas in a UNESCO reserve, comprising terrestrial, marine and coastal ecosystem. ${ }^{49}$

\subsection{The position of shale production in the EU MS}

Despite the potential economic advantages of shale gas production in the EU, its MS are widely and dived on whether they need to carry out the SG production and if there is enough regulation. ${ }^{50}$ The EU needs shale gas to augment its energy demands, but, however, different opinions on developing it emerge within EU member states which is likely to slow down the speed at which shale gas can be developed in the EU.

A significant figure of about $60 \%$ of the EU public does not want SG activities to take place in their territories as statistics worked on the proportionality of individual member state (MS) ${ }^{51}$ Other MS such as Poland consider SG production for bringing economic prosperity, creating more jobs and ensure energy security. ${ }^{52}$ Others are more worried about the harmful effects of HVHF in their respective countries calling for more scientific tests to be carried out on the potential environmental impacts of developing shale gas in their territories. ${ }^{53}$ Most prospective areas for shale gas development in the EU are found in densely populated areas which have very strong antifracking campaign groups in most EU MS, ${ }^{54}$ which makes access to land and land usage to be important issues especially in densely populated EU countries.

Figure 2 shows EU countries with SG deposits and shows which countries have issued a moratorium in HVHF, allowed it and those which have already issued permits.

States such as France and Scotland have imposed a moratorium on exploitation of shale gas. It is also problematic for the development of shale gas even in some countries willing to pursue shale gas activities projects due to immense pressure from anti-fracking groups. For example, in England, recently Lancashire county council rejected an energy firm, Cuadrilla a permit to start fracking on the Flybe Coast, an area located between Preston and Blackpool on grounds of, "unacceptable noise impact". 55

At EU level harmonised and consistent approaches are favoured by the majority of EU Citizens. Environmental NGOs prefer strengthening of environmental safeguards

\footnotetext{
$\overline{48}$ See footnote 34 .

${ }^{49}$ See supra footnote 8.

50 Fleming (2012).

51 Sreeramula (2013).

52 Bugarski and Maulet (2013).

53 Pearson et al. (2012).

${ }^{54}$ See supra footnote 3 .

55 Petroleum Review (2015).
} 
Fig. 2 EU MS shale gas deposits map. Source: International Energy Agency KPMG, press reports (2012)

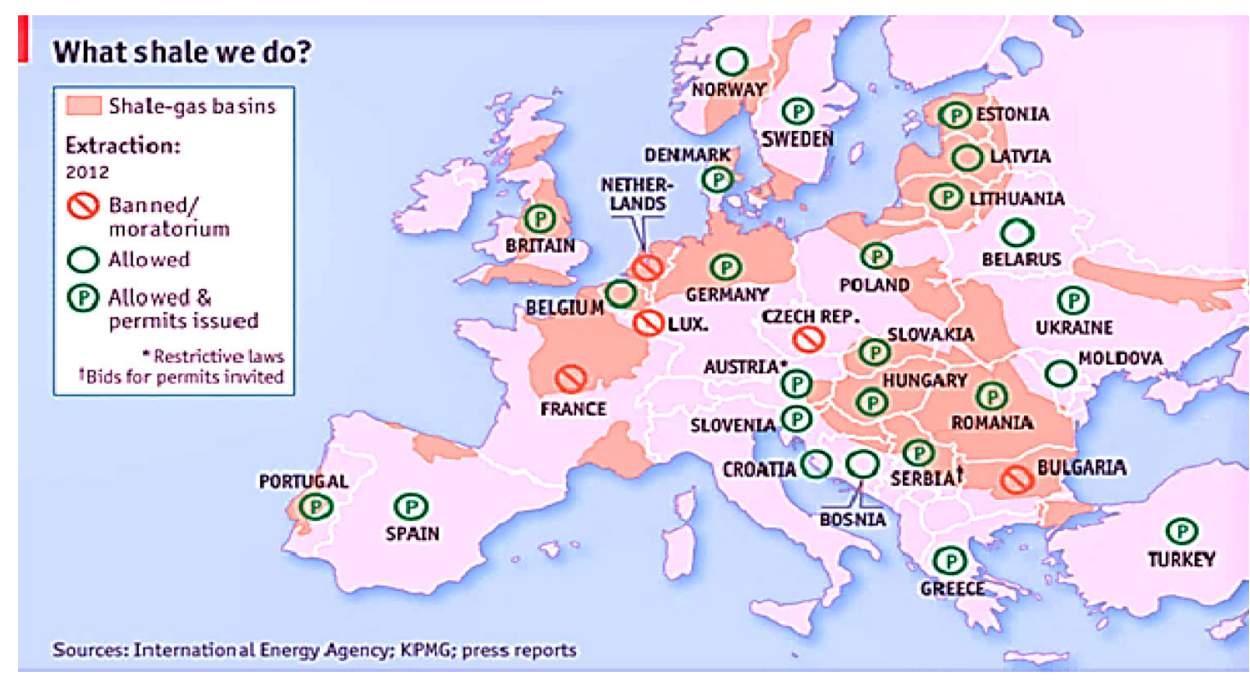

through regulatory framework. Soft measures and consideration of amending the existing law are preferred by the oil and gas industry, whilst specific comprehensive EU legislation was preferable to operators and service companies. ${ }^{56}$ However EU, member states are also widely dived on how the SG production projects should be regulated. ${ }^{57}$ These differences between organisations, the public and governments all add up to the complications involved in finding a legal lasting solution in regulating SG activities in the EU.

The nature of some of the impacts will be justify action to be taken at EU level where environmental impacts and the risks migrate from one MS to another, particularly surface and groundwaters as well as air quality and greenhouse emissions. ${ }^{58}$ Coordinated efforts by states which share boundaries where such projects are to take place in terms of programme management planning are important. This is discussed in more detail in Chapter 4 under strategic impact assessment (SIA).

The precise volumes of unconventional hydrocarbons available in the EU are uncertain as there are different estimates of technically recoverable SG in the EU from different sources. In 2013 the Federal Institute for German Geosciences and Natural Resources(BGR) estimated reserves to 16 trillion cubic metres (tcm), ${ }^{59}$ and in 2014 reassessment went down to $16 \mathrm{tcm}$ and in $2014 \mathrm{EU}$ Commission estimated it at $16 \mathrm{tcm} .{ }^{60}$ Some of these estimates also combine shale gas, $\mathrm{CMB}$ and tight gas together as

\footnotetext{
56 Directorate-General for Communication, Flash Eurobarometer 420.

57 Ibid.

58 The European Commission (2016).

59 Bundesanstalt für Geowissenschaften und Rohstoffe (BGR) [Federal Institute for Geosciences and Natural Resources] (2014).

${ }^{60}$ See supra footnote 58.
}

unconventional natural gas. The sustainability of the shale gas industry cannot be guaranteed and hence the need for taking precautionary measures in safeguarding the environment and the health of human beings form the effects of shale gas activities on any related projects that are taken. ${ }^{61}$

There is an estimation of $73 \%$ technically recoverable gas in the EU split between a number of counters ${ }^{62}$ which some of them have totally banned the shale gas extraction activities and the EU size of economically recoverable gas is also uncertain. Resources that can be produced with the available technology and able to make profit are what are called technically recoverable resource. ${ }^{63}$ Total bans were imposed in France, Bulgaria and Scotland whilst temporal moratorium on fracturing practices was imposed in Denmark, and North Rhine, in Germany on public concerns. Exploration projects which require the use of HVHF to carry out the tests may become impossible in some countries which makes it difficult to get the correct data.

Shale gas is infinite just like the rest of all other carbohydrates; therefore, it is essential to always be conscious that is will deplete in the end leaving an indefinite environmental and health impact which may not be proportional to the benefits that may be realised today.

\section{The EU SG environmental legislation}

The EU shale gas legislation is a made up of a Primary, secondary legislation, some EU and international legal principles. The EU has its legislative institutions which make and enforce the law on its entire MS. It is therefore important to analyse these institutions, their roles and how

\footnotetext{
${ }^{61}$ European Commission (2014).

62 Ibid.

${ }^{63}$ See supra footnote 2 .
} 
they make and implement law within its MS. Various legal principles applied in making the EU law and used by the courts to interpret the laws relating to the environmental impacts of shale gas activities shall also be analysed.

\subsection{The European Union, institutions and legislation}

The EU promotes and defends its values, objectives and its citizen's interests and its entire MS through its institutional framework. There are currently 28 states who are EU MS with Croatia being the most recent member to join in 2013. ${ }^{64}$ The membership is still growing and currently Turkey, Albania and three others are on the waiting list as potential candidates. The expansion of the EU membership, covering a very wide area with different, geography, demographics, geophysics, needs a very effective legal framework to address the impacts of shale gas activities. The EU is regarded as a region with environmental standards that are highest in the world and its current policy, the 7th Environmental Action Programme (EAP) 2010 outlined the EU institutions and MS' dual responsibilities and sets out long term strategy catering for environmental challenges. $^{65}$

The EU's the legislative powers generally lie with, the European Parliament (EP) where MPs are directly elected by EU MS citizens, the Council of the European Union (CEU) represents individual MS governments and tasked with setting EU overall political agendas but without powers to pass laws and is headed by a President on rotational bases. Then the EC is the EU's executive body which represents the whole Union's interests responsible for proposing and implementing EU laws. ${ }^{66}$ Then finally the ECJ is the EU's judicial body responsible for the application of EU law and making sure it is interpreted in compatible with the EU Law.

EU regulations take precedence over national laws of its MS and the EC is responsible for monitoring MS to make sure they implement and effectively enforce the EU legislation as directed and achieving the objectives of the directives. MS national courts judges can refer matters to the ECJ for preliminary ruling of EU law. Where a MS fails or delays to implement or acted in contrary to the EU legislation, the EC can warn the MS or issue proceeding in the ECJ for violating the EU law. ${ }^{67}$ Legal action will only be taken as a last resort otherwise the EC put greater emphasis on helping MS to effectively implement the law, capacity building and financial support. ${ }^{68}$ MS have the

\footnotetext{
${ }^{64}$ European Union, Countries (2016).

65 European Parliament (2016).

66 Europa (2016).

${ }^{67}$ COMM (2016).

68 The European Union Explained (2014).
}

rights to make their own environmental legislation in their MSs as long it is compatible with the EU law.

The Treaty on the Functioning of the European Union (TFEU) limits powers that can be exercised by the EU institutions. The EU institutions' power to issue environmental law is derived from Article 191 and 192 of the TFEU which can make regulations which have a direct effect $^{69}$ meaning that individuals can invoke EU provisions in a national court and get remedies without going to the ECJ directly.

The Lisbon Treaty empowers both EU institutes and individual MS powers to legislate on energy issues; however, MS can only exercise such powers provided the EU has not done so. ${ }^{70} \mathrm{MS}$ have a duty to make sure shale gas activities are regulated to the highest standards based on scientific and qualitative data, and making sure public participation is involved in the process is effectively monitored. ${ }^{71}$

There are a number of Treaties which forms part of the EU legislation relevant to the regulation of shale gas activities in the EU. Article 37 of the Charter of Fundamental Rights of the European require the environmental quality improvement and to be imbedded into the $\mathrm{EU}$ policies and protected at a higher level and also according to charter of the Treaty European on Union (TEU) and the TFEU. $^{72}$

\subsection{Legal principles shaping shale gas legislation}

The principles are some of the most important sources of the International and EU law, which are rules of human behaviour which have been in practice since time immemorial before the written law. These doctrines appear in many legal documents and are used by the courts in interpreting the law. Article 191 (2) TFEU outlines the settled rules of law which are clear and need not to be proved in court which the EU Environmental Policy is based on. ${ }^{73}$

\subsection{The precautionary principle}

EU institutions are urged to swiftly act without delay in situations where harmful consequences to the environment are strongly suspected of as provided in Article 191

\footnotetext{
$\overline{69}$ Case C-26/62, Van Gen den Loos [1963] ECR 1.

${ }^{70}$ Consolidated version of the Treaty on the Functioning of the European Union (TFEU) OJ C83/47.

71 Ibid.

72 Article 37 of the Charter of Fundamental Rights of the European on the Environmental Protection2012/OJ C 326/02.

${ }^{73}$ Scheuer (2016).
} 
(2)s 2 TFEU and Directive 98/81/EC. ${ }^{74}$ Prevention is better than cure; therefore, precautionary measures are to be applied in making decisions concerning shale gas activities. In doing so, the proportionality principle by weighing effects of the impacts on the environment against other needs such as energy, economic and security should also be observed. However, all MS have the freedom to decide taking measures at the highest level including not to pursue authorise or permit shale gas activities if they believe that would be the most appropriate safest thing to do.

\subsection{Principle of permanent sovereignty over natural resources (PSNR)}

The principle was established by the United Nations General Assembly (UNGA) in on its resolution 1314(XIII) 12 December $1958 .{ }^{75}$ The concept of PSNR is part of international law which gives sovereign states the primary responsibility over the rights of their natural resources and legal power to enter into agreements with other nations and international oil and gas developers to pursue extraction activities. $^{76}$ Under this doctrine, governments enjoy exclusive rights and freedom of national wealth and its distribution in their national interests. Individual states have the sovereign rights over natural resources lying between states and outside the jurisdiction of national states which belongs to the international community. ${ }^{77}$

This principle was adopted in the EU law under Article 1 of the Directive 94/22/EC ${ }^{78}$ directive which empowers MS as custodians and owners of natural resources in their geographical jurisdictions through their responsible authorities to permit any suitable and competent entity exclusive rights to explore and produce hydrocarbons. ${ }^{79}$ In the EU exploitation rights of the subsoil belong to the state and the surface remains the property of the landowner. This is different from the USA where mineral rights are owned by private individual who simply negotiate with a company to develop shale gas exploitation on his land on a fee or develop himself if he is capable to do so.

In many countries worldwide, minerals are owned by the state including in the EU member states. The owner of the land maybe is compensated for giving away land for mineral development. This may be the reason why there is

\footnotetext{
74 Hámor et al. (2010).

75 The United Nations, Human Rights, General Assembly resolution 1803 (XVII) of 14 December 1962.

76 Shaw (2008).

77 Nagan and Hammer (2004).

78 Directive 94/22/EC of the European Parliament and of the Council of 30 May 1994 on the conditions for granting and using authorizations for the prospection, exploration and production of hydrocarbons (1994) OJ L164/3.

${ }^{79}$ Ibid.
}

so much resistance in Shale gas activities in some EU MS State such as the UK. It could be on the basis of environmental or the "Not-in-my-backyard factor" (NIMBY) or and lack of incentive to persuade land owners or the local communities to consent to SG developments. The minerals belong to the state and central government reaps the benefits and not local government where the public might feel have a more direct benefit from projects that take place in their local communities. ${ }^{80}$

The PSNR doctrine was adopted into the EU law, under Article 194 (2), giving the EU member states the right to their energy mix of which they may choose to include or to exclude shale gas to be part of their energy national resource. ${ }^{81}$ Therefore, there is currently no jurisdiction for the EU over its member states on decisions on hydrocarbons or programmes for resource development.

Natural resources are described as naturally available raw materials that are not man made, that are accessible to sustain human needs in line with international law, national law, customs supported by international organisations that oversee resource trading. ${ }^{82}$

EU MS have the choice of authorising developers who meet their criteria for exploration and production shale gas in their territories and are responsible for the monitoring and enforcing EU law and their national shale gas exploration and production regulations.

The present regulation on shale gas development was not specifically crafted for shale gas activities but for conventional exploration and production activities; however, the EU commission in 2011 declared that it was also applicable to the unconventional exploration and production. $^{83}$

\subsection{The principle of subsidiarity}

Under the principle of subsidiarity, the EU can only act where member states cannot meet the objectives of any proposed action sufficiently at central, local, regional level or where the Union is in a better position to provide the best remedy due to the magnitude and effects of a problem. ${ }^{84}$ The EU is required to apply the principle of proportionality in achieving the objectives of the Treaties and not to act beyond what is necessary. ${ }^{85}$

The principle of subsidiarity tries to limit the EU's legislative powers and devolve regulatory powers to individual member states. This is in appreciation of the fact

\footnotetext{
$\overline{80}$ Dobra and Newman (2014).

${ }^{81}$ See supra footnote 70 .

82 Armstrong (2013).

83 See supra footnote 50 .

${ }^{84}$ See Article 5 of supra footnote 70.

${ }^{85}$ See supra footnote 70 .
} 
that traditions within Europe are diverse where certain issues are best dealt with at national level rather than at EU level. ${ }^{86}$ The EU law under the principle of subsidiarity allows MS to make domestic laws that are suitable for governing shale gas extraction activities in their territories in addition to the available relevant EU regulations.

The EU MS have the duty to make laws and policies to administer and control the environmental effects of any shale gas extraction activities they authorise in their jurisdictions because the closeness to their environment increases their strength of responsibility. ${ }^{87}$

\subsection{The Golden Rules}

The International Energy Agency (IEA) developed a set of, "Golden Rules" aimed at opening ways of a massive shale gas unconventional development by suggesting policies that can be used by policy makers, regulators and operators in addressing environmental social impacts of shale gas activities. The Golden Rules encourage local community engagements, monitoring environmental impacts and transparency as a way of gaining social licence to operate. ${ }^{88}$ The Golden Rules recommend effective regulatory regimes for safe development of unconventional gas in terms from planning, development, risk assessments and monitoring-related potential impacts and management of wastewater management and reduction in greenhouse emissions. ${ }^{89}$ EU MS can apply these Golden Rules in developing their own environmental shale gas policies to regulate their national shale gas activities.

\subsection{Shale gas legislative developments in the EU}

The EU's legislation for shale gas exploration and production is made up of various EU pieces of legislation comprising the acquis commununutaire, treaties, regulations and directives and decisions as well as recommendations. The EU has over the years been working out to improve the effectiveness of shale gas legislation in making sure they are good enough to deal with the potential environmental impacts. The European Council in 2011, called for an assessment of sustainable extraction and enhancement of energy security by using the unconventional carbohydrates in the EU. A number of reports followed which ended up with a recommendation in 2014.

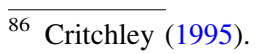

87 See supra footnote 3 .

88 See supra footnote 3 http://www.worldenergyoutlook.org/media/ weowebsite/2012/goldenrules/weo2012_goldenrulesreport.pdf. Accessed on 27 March 2016.

89 See supra footnote 3 .
}

\subsection{Philippe and partners commission report}

The Director-General for the Energy of the European Commission awarded a tender to Philippe and Partners based in Brussels to make a report on the EU environmental legislation's appropriateness to shale gas projects. In November 2011 a report was published on the transposition of EU Directives into national law enabling MS to regulate shale gas activities in their jurisdictions. ${ }^{90}$

The report also stated that there was no noticeable gap at the European level or national level in regulating shale gas in Germany, France Poland and Sweden.

The report was, however, criticised for being biased because the law firm Philippe and Partners had a lot of shale gas company clients involved in shale gas activities in the EU. ${ }^{91}$ This was a clear conflict of interest which the law firm should have recused itself from bidding or being awarded the tender to compile such a report.

When new regulatory provisions are introduced, they have financial implications on the developers and governments implementing them. The Environmental Impact Assessment (EIA)'s difficulties in implementing have been fruitful to environmental Lawyers in the EU by representing parties in national courts and commission proceedings. ${ }^{92}$ EIA is costly because it needs teams of expert consultants and teams of lawyers to look into any related challenges. These cases are voluminous and can take years to resolve meanwhile solicitors will be making money. ${ }^{93}$

Therefore, a law firm with clients already in this field cannot be seen to be making a fair and equitable report on issues involving their clients' interests, its unethical.

\subsection{European Commission EIA guidance 2011}

The EC published guidance on how to apply the EIA Directive to advanced techniques as the hydraulic fracturing and horizontal drilling in $2011 .{ }^{94}$ This directive ensures the permitting process include environmental issues with potential significant environmental effects, how public should be involved in decision making in granting permissions. This guidance also explained the thresholds which the EIA would become mandatory. The conclusion was that there is already a comprehensive environmental legal framework that is applicable to both conventional and

\footnotetext{
$\overline{90}$ European Commission (2012).

91 Aitken et al. (2012).

92 Simons (2014).

93 ibid.

${ }^{94}$ Guidance note on the application of Directive 85/337/EEC to projects related to the exploration and exploitation of unconventional hydrocarbon.
} 
unconventional carbohydrates activities from permitting to decommissioning. ${ }^{95}$

\subsection{Janez Potocnik: transmission note}

As public concern continued to haunt shale gas activities in the EU, the European Parliament (EP) requested for guidance from the European Commission's Environment Commissioner on carbohydrates unconventional exploitation legal framework. A note was issued on the 20 January 2012 outlining the drilling and hydraulic fracturing of shale gas wells and its production and the potential environmental impacts at different project stages and explaining the existing EU law relevant to such activities. ${ }^{96}$ EIA was confirmed to apply at authorising stage of the project and the need for public participation permitting in decision making. It basically explained issues covered by the already existing directives and did not point out any new risks not covered already.

\subsection{European Commission public consultation}

A public consultation was initiated by the EC for the period of December 2012 to March 2013 asking whether the public approve unconventional hydrocarbons development in Europe and their opinion on the existing legislation's adequacy by considering given five alternatives. The indication from the responses from the public showed that there was need for additional action to be taken on the regulatory framework at EU level and need for a comprehensive new regulation framework. ${ }^{97}$

\subsection{European Commission studies}

A number of studies were then commissioned by the EC to assess the shale gas impacts on market and climate change, human and environmental risks, application of regulatory provisions and chemical registration usable in hydraulic fracturing. This study was a bit more critical and came out with a number of conclusions. The study concluded that MS generally relied on the Mining and environmental legislation adopted from the EU available legislation being applied without any distinction between conventional and unconventional oil and gas. Uncertainties in certain EU legislation were found, especially on how flowback fluids should be treated. Lack of knowledge within MS on the areas covered by the EIA to shale activities and impacts that are accumulative on the project was also identified. The report also found that there was no legal requirement

\footnotetext{
95 Vopel (2012).

96 See supra footnote 27.

${ }^{97}$ McArdle and Gilhooly (2014).
}

for casing and cementing on unconventional wells whilst other countries such as the UK apply their own design, construction and integrity rules of 1996 which are also applicable to conventional wells. ${ }^{98}$

\subsection{The 22 January 2014 commission recommendation $(\mathrm{CR})$}

The EU Environmental legislation was not done with shale gas activities in mind, and therefore, there is no specific shale gas legislation other than the general environmental legislations which covers other industrial and environmental issues in the EU. The EC after having promised to table new laws to regulate shale gas extraction, decided to let the MS governments to take charge of this controversial activity. The EU Commission decided to propose a set of recommendations outlining the minimum standards to its MS to maintain environmental standards. ${ }^{99}$

This CR was adopted by the EC on activities specifically concerning HVHF on shale gas and oil exploration and production activities in the $\mathrm{EU}^{100}$ and defined $\mathrm{HVHF}$ activities as those with a water injection in excess of $1000 \mathrm{~m}^{3}$ of water per well or $10,000 \mathrm{~m}^{3}$ for the entire fracturing process. This can technically exclude activities which do not HVHF up to these thresholds and that could be a loophole to escape the recommendations and risk to environment.

The key recommendations included the strategic planning and impact assessment, permitting, exploration and production, site selection and baseline studies throughout the whole production process up to post operation closure and surveying. ${ }^{101}$

The framework of the recommendations encourages all member states who wish to engage in shale gas extraction to apply a set of protective measures that are common and of minimum standards in addition to the existing EU Law. ${ }^{102}$ The interested countries are encouraged to carry out an EIA before issuing high-volume fracturing licence $^{103}$ and have to be done for each individual shale gas project. $^{104}$

According to EU law, Regulations, Directives and Decisions are legally binding at different degrees. Recommendations and Opinions are not legally binding but constitute soft law which may not have direct effect.

\footnotetext{
98 HSE (2016).

99 See supra Fig. 1.

100 See supra Fig. 1.

101 See supra Fig. 1.

102 See supra footnote 38.

103 See Article 3.1C of supra footnote 34.

104 See Article 3.3 of supra footnote 34
} 
However, Recommendations have been urged to be taken into account by national courts by the ECJ as a tool for interpreting national laws. These can also be used by administrative staff and quasi-judicial authorities who deal with shale gas projects processes. ${ }^{105}$ The CR is not being followed by MS as recommended due to its weaknesses, attitudes and competences of certain MS in implementing EU law. More analysis and a number of examples are given in Chapter 4.

\subsection{EU environmental law enforcement}

There are a number of environmental breaches that are committed by MS such as failing to communicate implementing measures for directives to the Commission, failure to comply with ECJ judgements within a reasonable time and breaching EU law with far reaching consequences. These are to be resolved and enforced through the available judicial processes at EU level in the ECJ and within the EU MS's national courts, the National Ombudsmen and the Alternative Dispute Resolution (ADR) processes which some MS have established a self-regulatory mediation culture whilst in some it still developing.

\subsection{The role of the European Court of Justice}

It is the responsibility of the EC as, "the guardian of treaties", to enforce the community environmental law and make sure MS comply with the apply TEU and TFEU and all measures covering environmental impact issues. ${ }^{106}$ The Commission has got the power to bring MS that fail to comply with the EU treaties before the ECJ. ${ }^{107}$

The court may find the MS liable for damages or loss caused by its failure to enforce the environmental law under the principle of state liability. ${ }^{108}$ If there are any complainants claiming damages, they have to satisfy that the rule of the EU that was infringed was intended to confer them rights, and there must be a serious breach of the rule and an established connection between the breach and the damages suffered by the individual. ${ }^{109}$

MS Judges can refer a question to the ECJ on how to interpret EU Directives and not hypothetical problems or those which have already been decided or resolved. Any decision made by the ECJ is binding and is superior than EU MS states domestic courts. The ECJ can only deal with

\footnotetext{
105 see supra footnote 50.

106 See Article 17(1) of supra footnote 70.

107 See Article 258 supra footnote 70.

108 Case C-429/09 Fub [2010] ECR I-12167, paragraph 45.

109 C-568/08 Combinatie Spijker Infrabouw-De Jonge Konstruktie and Others [2010] ECR I-12655.
}

complains referred by the MS national courts which have jurisdiction to deal with such matters and can impose fines which are quite substantial and calculated at in relation to GDP on MS failing to comply with its decisions within a reasonable period. ${ }^{110}$

\subsection{National courts}

MS national courts have jurisdiction to deal with environmental breaches that occur in their territorial jurisdictions under the civil process or criminal process under Directive 2008/EC. ${ }^{111}$ It is a strict liability offence to breach a national environmental statute provision which can be an EU directive transposed into an EU MS national law or an EU regulation which has a direct effect in all MS.

\subsection{Quasi-judicial process: the Ombudsman}

Ombudsmen were suggested to be involved in handling environmental complains within their member states but some States such as Italy and Germany have no Ombudsmen. In most countries Ombudsmen deal with reviewing public bodies decisions and handle disputes of individuals with administrative bodies. It has been recommended that each MS should have an Ombudsman as an independent establishment to handle public environmental complains. ${ }^{112}$

There are, however, other weaknesses in utilising the Ombudsman's office to deal with environmental matters besides that they are not established in every EU MS. Ombudsmen have got a discretion to lounge an investigation of any complaint made to their offices and they may decide not to pursue some shale gas environmental disputes. Operational financial difficulties and lack independence for example in France where only complaints referred by a Member of Parliament. Lack of environmental knowledge has been identified as a weakness in utilising the Ombudsman in dealing with environmental disputes. ${ }^{113}$ It is high time special environmental courts are also set up in the EU like the, Green Benches in Brazil. ${ }^{114}$ The EU Forum of Judges for the Environment for exchanging views on the implementation and interpretation of EU law and training national sitting judges on Environmental issues which is supported by the Environmental Directorate General since it was established in 2004 is also

\footnotetext{
$\overline{110}$ Duncan Brack (2001).

111 Directive 2008/99/EC of the European Parliament and of the Council of 19 November 2008 on the protection of the environment through criminal law.

112 The European Union, Environment (2014).

113 European Parliament, Compliancy Promotion (2012).

114 Benidickson et al. (2011).
} 
doing a good service for the towards effective judicial environmental protection. ${ }^{115}$

\subsection{Alternative dispute resolution (ADR)}

ADR would be best suited for resolving environmental conflicts which are complex and challenging. Environmental problems that can be resolved included among other things, culture, property rights legal and regulatory matters which can be brought by private individuals, members of the public or can be multijurisdictional and by those with special interests. ADR has its advantages over legal and regulatory processes besides saving money and time, stakeholder's ownership and confidentiality it is has a holistic approach and takes a wider picture a wider picture on the environment and not on a particular development. ADR has been used in the United States of America in a number of environmental disputes relating to shale gas activities. ${ }^{116}$

\section{The EU shale gas regulatory framework}

The EU shale gas exploration and production activities are regulated in the existing EU legislation dealing with authorisation of carbohydrates prospection, exploration, production and other connected activities even though this legislation is not specific for shale gas activities but have fracking features. ${ }^{117}$

The CR point (7) states that hydrocarbon exploration and productions involving HVHF are covered under the general EU environmental law and other various directives which the EU MS can use in regulating SG activities. The important permitting and operational regulations recommended by the commission and other EU relevant to shale gas activities will be critically analysed.

\subsection{Permitting and licensing regulations}

Any exploration and production of hydrocarbons including shale gas has to be authorised by each MS as the controller of its natural resources through its competent authority. Hydrocarbon exploration and production plans have to go through the licensing and permitting procedures first before any development takes place. It is the responsibility of a competent authority to deal with authorising activities on behalf of the individual States. ${ }^{118}$

\footnotetext{
115 European Commission, Environment (2016).

116 Disputes in the energy sector financier Worldwide October 2014 (2014)

117 European Commission DG Environment (2012).

118 See supra footnote 78 .
}

Generally, the process of exploration is to identify the resources and its quantities and to assess its viability to exploit, technically and economically before the production of the hydrocarbon extraction process can commence. $^{119}$

MS are prohibited to be discriminatory in the process of issuing of authorisations and permits for exploring and hydrocarbons, including shale gas. ${ }^{120}$ An entity established in another EU member state is free to establish business and provide services in another MS without any restrictions. ${ }^{121}$ Entities from third nations may also be granted permission at the discretion of the MS where development is to take place. The authorities grant exclusive rights of exploration and exploitation of hydrocarbons to the developer for an agreed period in a specified geographical area by issuing a licence, and then a permit is required for doing the actual operations, which both can be referred to as "concessions". 122

The EU general environmental directives are applicable to exploration and production of carbohydrates involving HVHF. These directives among other things outline the legal framework for competent authorities to carry out impact assessments and issuing of permits.

\subsection{Strategic environmental assessment (SEA)}

The SEA) Directive (2001/42/EC) focuses on issues involving programmes plans and polices determining the overall bigger picture to achieve certain goals. ${ }^{123}$ SEA can protect the environment which we all depend on especially the poor people, by promoting sustainable development and poverty reduction. It is an essential tool in making strategic decisions on policy, planning and programmes. A number of developmental outcomes can be achieved by integrating the environment and development by making decisions based on environmental evidence. Opportunities are then easily identified, preventing expensive mistakes and promoting decision making through public engagements which improves governance and facilitating transboundary cooperation. $^{124}$

It is a good way of managing successful projects because every stage is reviewed periodically and actions

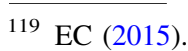

${ }^{120}$ European Commission (2012).

121 Article 56 of the Consolidated version of the Treaty on the Functioning of the European Union-Part Three: Union Policies and Internal Actions- Title IV: Free movement of persons, services and capital-Chapter 3: Services (2008) OJ115 P0070.

122 European Commission (2012).

123 OECD (2006).

124 ibid
} 
have a timeline and all the components are part of the strategic plan. ${ }^{125}$

A SEA is the first step to be taken by an authority in considering permits for prospecting, exploration and the production of hydrocarbons. Where a development is at a large scale an assessment of impacts should be carried out from constructing the well site and carrying out seismic tests and preliminary drilling. An SEA needs to be carried out before the licences are issued on projects requiring HVHF. This assessment reports on potential impacts on the environment, biodiversity, population, water, air, flora, fauna, climatic conditions, cultural and archaeological heritage, landscape and human health.

Projects that are commenced without an SEA have the potential of being overwhelmed with the impacts of risks at a later stage which could be identified if a AEA is take at earlier stages. Figure 3 illustrates the decision making hierarchy in programmes, plans, projects and policies. Figure 3 shows how the SEA integrates environmental considerations in plans and programmes at policy level taking in the context of the political, governance and institutional process of making decisions. ${ }^{126}$ This is where all risks are assessed, eliminated and strategizing risk mitigation on individual projects before they commence. All this has to be done in line with the outcomes of the initial assessment of the whole programme. This will strategically eliminate conflicts as the project progresses by giving this overall territorial planning approach (Fig. 3).

The IEA also recommended countries to take strategic planning in regulating large industrial operations of unconventional production which is more evasive than the conventional activities. In its "Seven Golden Rules" the IEA recommended that timely interventions and early strategic assessments should be carried out by public authorities before any project commences. ${ }^{127}$

The EU Commission Recommendation clearly stated that a strategic environmental assessment should be prepared in terms of the Directive 2001/42/EC before HVHF exploration or production licences are issued. ${ }^{128}$ The Espoo Convention in 2003 also promoted the use of SEA in national legislative and policy decisions in a trans-boundary context. ${ }^{129}$

SEA Directive requires all government programmes including those financed by the European community whose plans are capable of having significant environmental impact

\footnotetext{
125 ibid.

126 See supra Fig. 1.

127 See supra footnote 3 .

128 See supra footnote 27.

129 UNECE (2003).
}

to be strategically assessed by all MS. ${ }^{130}$ The aim of SEA is to assist the authorities with necessary information in making decisions involving HVHF processes. Shale gas as a natural gas requires SEA as part of country planning. ${ }^{131}$

It is then surprising that some MS do not follow this recommendation which is a good project management strategy followed by many organisations which manages projects as a matter of good practice. The idea of jumping straight into running projects is a risk way of conducting any type business projects because it lacks risk evaluation, unsustainable and results in poor quality of outcomes. ${ }^{132}$

\subsection{Are the member states complying with SEA?}

The SEA directive has been breached by a number of the MS despite its importance and recommendations. Spain rejected implementing SEA, arguing that exploration licence applications cannot be considered plans or programmes because the area to be assessed will not be awarded to anyone yet or a pending request for an award, except when the area was offered by the Autonomous Regional Government or the Council of Minister which require a SEA. ${ }^{133}$

Poland also argues that issuing of shale gas licences is an administrative decision and not plans or programmes which need SEA and went ahead and issued hundreds of exploration permits. It issued the Zwierzzyniec permit to Chevron covering a very wide area of Natura 2000 sites as well as Roztocze National Park a UNESCO, "biosphere", reserve, meaning it comprises terrestrial, marine and coastal ecosystem ${ }^{134}$

The United Kingdom DECC which is responsible for issuing licences to explore hydrocarbons under its Petroleum Act $1988,{ }^{135}$ on its 13 shale gas licensing rounds it issued Cuadrilla's licences in Lancashire (PEDL) 165 and Balcombe site in West Sussex without conducting SEA, thereby breaching Directive 2001/42 and the Commission Recommendation (3.1) $)^{136}$ All these breaches can result in serious damage to the environment and human health. It is clear that as SEA covers a bigger programme area where licences will be issued for individual projects and then EIA should be done on every project authorised to take place.

\footnotetext{
130 Directive 2001/42/EC of the European Parliament and of the Council of 27 June 2001 on the assessment of the effects of certain plans and programmes on the environment (2001) OJ L19730.

131 See footnote 123.

132 ibid.

133 See supra Fig. 1.

${ }^{134}$ See supra Fig. 1.

135 Section 3 of the Petroleum Act 1988 (UK).

${ }^{136}$ See supra footnote 8 .
} 
Fig. 3 SEA: the interaction of environmental into decision making. Source: OECD (see supra footnote 123)

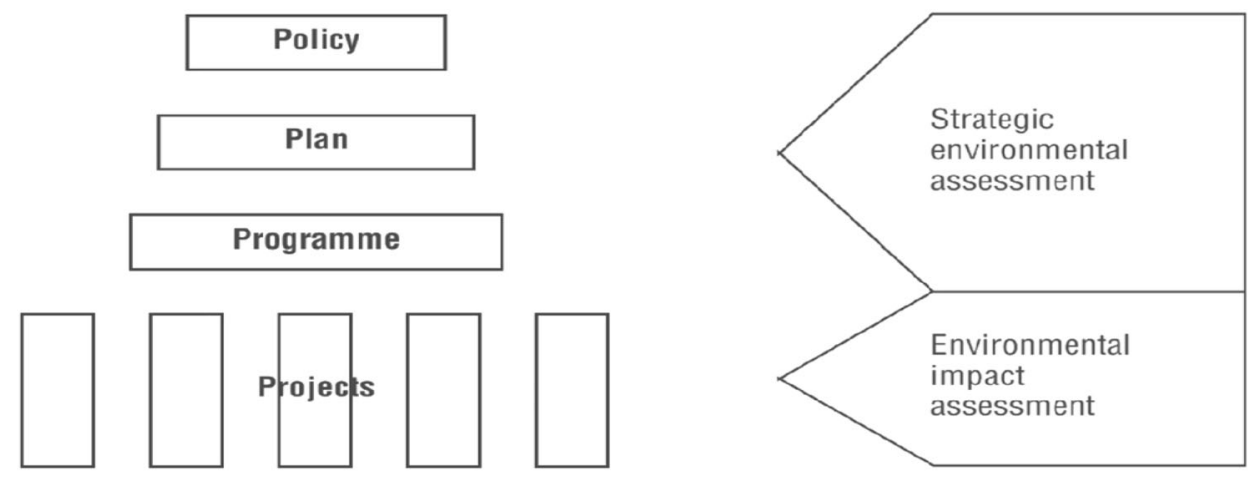

\subsection{Environmental impacts assessments}

The EIA 2011/92/EU as amended by Directive 2014/52/EU ensures that significant environmental impacts are identified and accordingly addressed before decisions to allow a project that may have environmental impacts to proceed. ${ }^{137}$ This directive has a wide scope and intended for a broad purpose. ${ }^{138}$ It, however, fails to take into account the peculiar features of a shale gas well. A shale gas well rapidly declines its production, lower in gas production per well as compared to a conventional well production and cumulative impacts from high number of wells required.

EIA is mandatory for commercial natural gas extraction projects with a production exceeding $500,000 \mathrm{~m}^{3}$ per day. ${ }^{139}$ This is unlikely to be achieved considering the EU's shale gas production rates. A shale gas well produces roughly $250,000 \mathrm{~m}^{3}$ in its initial stages reducing to less than $100,000 \mathrm{~m}^{3}$ per day which makes it below the threshold for the EIA to be compulsory. ${ }^{140}$

The EC and the European Council in 2014 EIA review rejected clauses voted for by the EP on the 9 October which was calling for shale gas activities to be included under mandatory EIA Annex 1 of the EIA Directive. This could have made shale gas hydraulic fracturing classified as an activity having significant effect on the environment, thereby requiring compulsory EIA under Annex $1 .{ }^{141}$

137 Directive 2011/92/EU of The European Parliament and the Council of 13 December 2011 on the assessment of the effects of certain public and private projects on the environment as amended by: Directive 2014/52/EU of the European Parliament and the Council of 16 April 2014 Environmental impacts Assessment Directive (2011/ 92/EU).

138 (C-72/95, Kraaijeveld and Others), paragraphs 31, 39.

139 See supra footnote 126, Annex 1 (14).

140 Supplemental generic environmental impact statement on the oil, gas and solution mining regulatory program well permit issuance for horizontal drilling and high-volume hydraulic fracturing to develop the Marcellus Shale and other Low-Permeability Gas Rese (2011).

${ }^{141}$ See supra footnote 92 .
The provisions do not specifically provide for multi-wells cumulative production under Annex 1 of the directive ${ }^{142}$ Shale gas projects can have many wells drilled on a project, and as in-re Brussels Hoofdstedelijk Gewest, ${ }^{143}$ the cumulative effect of several projects cannot escape the impact assessment obligation since combined impacts from a number of wells can cause significant effects on the environment under Article 2 (1) of the EIA Directive. Therefore, even if the directives do not expressly say that accumulative impacts from several wells on a project should be assessed together case law has clarified that shortfall.

According to a study carried out by Milieu limited on behalf of the EC Directorate General Environment, certain EU MS countries made EIA a mandatory requirement for unconventional gas exploration and production, for example, Bulgaria made it mandatory since 2012, it is also mandatory in Denmark and in Lithuania for both conventional and unconventional exploitation of hydrocarbons. Other MS simply adopted the EIA Directive without indicating whether that applies to unconventional or it is part of the process. ${ }^{144}$

\subsubsection{EIA weaknesses}

There are inconsistences in the application of the directive between MS; however, various legal assessments done by the DGs of the EC and the EP agree that EIA should be part of the, "best practice" in unconventional fossil fuel projects. ${ }^{145}$

As public concern continued to haunt shale gas activities in the EU, the European Parliament (EP) requested for guidance from the European Commission's Environment Commissioner on legal framework unconventional carbohydrates exploitation. A note was issued on the 20 January 2012 outlining the drilling and hydraulic fracturing of shale

\footnotetext{
142 COMM (2012).

143 C-275/09, Brussels Hoofdstedelijk Gewest and Others.

144 See supra footnote 31 .

145 Ibid
} 
gas wells, its production, the potential environmental impacts at different project stages and explaining the existing EU law relevant to such activities. ${ }^{146}$ EIA was confirmed to apply at authorisation stage of the project and that public participation was needed in the process of making permitting decision.

Impacts not known prior to the EIA exercise cannot be assessed and can lead to an unanticipated pollution to unknown aquifers in the surrounding geographic area and lack of obligation for geological assessment.

A decision to grant exploration and production permit by a responsible authority may not be through public participation or based on impact assessment therefore possible impacts may not be known and assessed especially where the process is by consent. ${ }^{147}$

\subsubsection{MS monitoring capacity and competency}

Competent authorities require adequate human manpower, technical and financial resources in order to do their duties diligently as recommended in chapter 13 of the CR. ${ }^{148}$ However, according to the technical risk management report by AMEC on behalf of the ECDG environment, this policy option attracts higher compliancy costs per-year per pad as compared to tight gas, oil and CMB compliancy costs. ${ }^{149}$

The lack of capacity to monitor and enforce the regulations independently by MS competent authorities shows that some MS just transpose the legislative text but do not enforce as required by the law. There have been issues concerning conflicts of interests and corruption activities related to shale gas authorisations in some MS. The following examples illustrate MS which failed to prevent conflicts of interests in terms of Section (2) of Chapter 13 of the recommendations.

The first example in the UK, Sir Phillip Dilley was appointed as the chairman of a UK Environment Agency with the responsibility for granting permits for fracking across the UK. Mr Dilley had been the chairman of Arup an engineering company which was responsible for writing reports for Cuadrilla, a shale gas developing company in the UK. ${ }^{150}$ An independent investigation in December 2014 found out that $£ 2.3 \mathrm{bn}$ was invested in fracking investment companies by the UK Environmental Authority. ${ }^{151}$ The likelihood is that the majority of the decisions are favourable to the state to the detriment of other

\footnotetext{
146 See supra footnote 28.

147 See supra footnote 31.

148 See supra footnote 34.

149 See supra footnote 26.

150 Mason (2014).

151 Rowell (2014).
}

stakeholders and indirectly impacting public health and the environment.

Another example is that the Polish Geological Institute, the Environmental Ministry and Gas Company officials were indicted on licensing corruption charges. ${ }^{152}$ The Polish Supreme Audit Commission 2014 reported some irregularities on public administration and private entities interested in shale gas exploration in Poland. The Commission found that there was no appointment of a government official who was overseeing the overall management controls of shale gas activities. ${ }^{153}$ There were only three officials with the responsibility of issuing licences between 2007 and 2012, and decisions were made by the Environmental Minister himself. The decisions were taking an average of 132 days instead of 30 days as required by law and officials were accepting bribes for helping developers to win concessions. ${ }^{154}$

Romania lacks technical expertise and its national regulations allow hiring of specialist's agencies whenever needed. The national authorities failed to organise specialist agencies despite being requested by its local environmental authority for carrying out environmental assessments on four wells in Barlad Region. ${ }^{155}$

The chances of achieving the objectives targeted by the Recommendation are compromised in such situations where there are elements of corruption and conflicts of interests. Concessions will be awarded unfairly to entities that pay higher bribes that may not have the necessary expertise and financial backing strong enough to carry out such big delicate projects successfully, putting risks to the environment and human beings.

\subsubsection{Public participation}

The CR 2014 recommends public authorities in the EU to involve public participation and access to the justice system on environmental matters. ${ }^{156}$ This would give assurance to the members of the public concerns about fracking if they are involved in drawing up plans or programmes in accordance with Directive 2003/35/EEC as amended. ${ }^{157}$ The EIA Directive was amended in 2014 aimed at

\footnotetext{
152 Natural Gas Europe (2012).

153 See supra footnote 8.

154 France-Presse (2013).

155 See supra footnote 8 .

156 UNECE (1998).

157 Directive 2003/35/EC of the European Parliament and of the Council of 26 May 2003 providing for public participation in respect of the drawing up of certain plans and programmes relating to the environment and amending with regard to public participation and access to justice Council Directives 85/337/EEC and 96/61/ECStatement by the Commission.
} 
strengthening public participation, transparency reflecting the dynamics of the environment, changes in the society and regulatory challenges. ${ }^{158}$

Shale gas projects needs a social licence to operate, which is an acceptable level of approval given to developers by the stakeholders especially the local communities that are impacted by such developments. These are a set of mutual trust based relationship between operational stakeholders. ${ }^{159}$ Multinational companies pursuing shale gas activities should aim to meet the diverse expectations the local communities as well as the NGOs to ensure they do not put their reputation in jeopardy subjecting themselves to all forms of destabilisation resulting in discontinuation of projects whilst incurring huge financial costs. ${ }^{160}$

There is need for a Free, Prior and Informed Consent (FPIC) by developers which is a human right-based approach ensuring the right of indigenous peoples to selfdetermination. ${ }^{161}$ There should be no pressure or cohesion from the organisation or the state. Consent should be sort before any activities are carried out and the project should be explained in an unambiguous language clearly understood by the local community. ${ }^{162}$

International financial institutions will not provide funding for developers who do not want to commit to the global finance industry's corporate social responsibility and sustainability framework aka the Equator Principle aimed at assessing and managing environmental and social risks on all international projects. ${ }^{163}$

Members of the public and NGOs should be afforded the opportunity to make comments which competent authority would take into account in making project development decisions. The need to inform the public about all final decisions, how the environmental impacts will be put under control and how compensation for damages will be worked out. The public is entitled to retain the right to object to the decision in court if they disagree. ${ }^{164}$

The public is not being given enough opportunity to participate in permitting decisions in some MS, and for example in the UK as from August 2015 Ministers were authorised to upset the local authority's decision where

\footnotetext{
158 Directive 2014/52/EU of the European parliament and of the Council of 16 April 2014 amending Directive 2011/92/EU on the assessment of the effects of certain public and private projects on the environment.

159 Moffat and Zhang (2014).

160 Boutilier (2014).

161 International Institute for Environment and Development All rights reserved Copyright (2013).

162 See supra footnote 160 .

163 IFC (2016).

164 The European Commission (2015)
}

they felt a shale drilling application is taking too long. ${ }^{165}$ In this case the public will not get any opportunity to make meaningful contributions even if they are given the chance to do so. A good example is as when the public were given three weeks to go over 9000 pages of environmental statements from a developer, Cuadrilla where an application was made for an extension of time. ${ }^{166}$ It is absurd that ordinary members of the public or even professionals would be expected to digest a 9000-page document involving a specialised project, with a lot of technicalities within three weeks and which may also need consultation before commenting.

\subsection{Operational regulation provisions}

\subsubsection{Wastewater management}

Dealing with millions of gallons of HVHF wastewater is a big issue. In the USA it is injected in deep well injection sites, which in Texas 8000 disposal wells and 25,000 for waste fluids. ${ }^{167}$ Over the period between 2008 and 2009 public sewage plants were used to dispose wastewater from HVHF projects in Pennsylvania where 271 cases have been confirmed cases of waterways degradation from shale gas hazardous waste. ${ }^{168}$ The EU MS should learn from the USA experience and not repeat the same mistakes which some of them have solutions available.

In the UK wastewater was discharged into Manchester Ship Canal after going through a local facility basic water treatment ${ }^{169}$ and German's Environmental Agency recommended deep well injection or recycling but cautioning that there was not yet the best sustainable waste management practice. ${ }^{170}$ This indicates how desperate the industry is in managing wastewater which so far in the EU can only be protected by Mining Waste Directive (2006/21/EC) not specifically drafted to deal with HVHF risks.

Operators are to comply with certain specific obligations in accordance with the directive. Any substances which the operator is by law required to dispose or intends to do so is classified as waste ${ }^{171}$ including drilling muds ${ }^{172}$ and water from HVHF. ${ }^{173}$

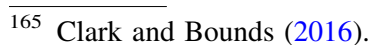

166 Lancashire County Council (2014).

167 Henry and Galbraith (2016).

168 Peltier et al. (2016).

169 Banks and Reporter (2001).

${ }^{170}$ Ittershagen et al. (2014).

171 Article 3 (1) of the Waste Directive (2008) 98/EC

172 Commission Decision of 18 December 2014 amending Decision 2000/532/EC on the list of waste pursuant to Directive 2008/98/EC of the European Parliament and of the Council.

173 Mining Waste Directive (2006)/21/EC.
} 
A waste facility for HVHF processes will need a permit from a competent authority to be allowed to operate. ${ }^{174}$ The permit put measures in place at waste facilities to prevent accidents and environmental impacts and for waste management related facilities on the site. Wastewater discharged to the surface is also regulated by a permit under the Mining Waste Directive, Industrial Emissions Directive and Water Framework Directive which were all not meant to deal with specific risks emanating from shale gas activities. It is the duty of the operator to put in place regular monitoring and inspection arrangements of the waste facility by competent staff and taking measures that threaten water or soil instability and contamination. ${ }^{175}$

EU law requires MS to decide on the frequency of inspections on operators' waste management facilities and records on projects by is carried out by their competent authorities. Operators have to keep waste management records updated and ready for inspection by competent authorities and the records should be appropriately transferred in the event of changing operators. ${ }^{176}$

The wastewater should be stored in a specially built facility and then transported to a waste treatment facility before re-reinjection. However, most storage facilities are open pits where dissolved gas and petroleum components can evaporate, liners leak. Overflow after rainfalls can also occur, leading to ground contamination and can catch fire with lightning because of the petroleum components. ${ }^{177}$ There are a number of fracking water spillage incidents which happened in many places in the USA resulting in loss of livestock and environmental damage over vast tracks of land. ${ }^{178}$ These serious incidences can also happen anywhere in the EU where shale gas activities are taking place if not properly managed.

\subsubsection{Water quality}

Shale gas activities affect water through abstraction and chemical pollution and by flowback water. The abstraction depletes surface water resources whilst chemicals contaminate both surface water and groundwater. ${ }^{179}$

HVHF uses very large volumes of water estimated at more than $15,000 \mathrm{~m}^{3}$ per well, ${ }^{180}$ for example at Lebien LE-2H well in Poland approximately $18,000 \mathrm{~m}^{3}$ of water was used for drilling. ${ }^{181}$ Drawing such large quantities of water may

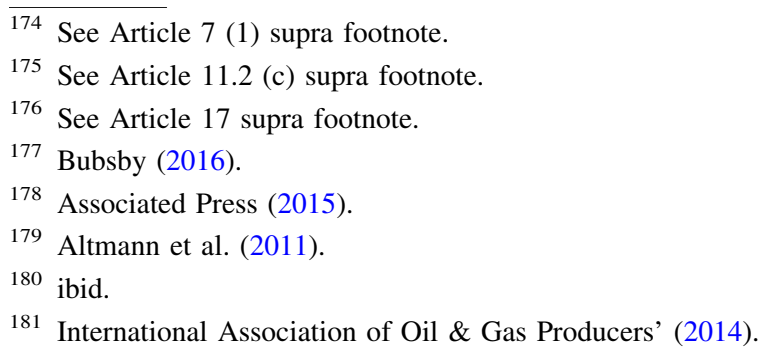

result in the depletion of water from the resources and affecting the environment depending on such resources. That can also create shortages of water supply to the communities using the same sources for their water supply. ${ }^{182}$

\subsubsection{Surface water}

The Water Framework Directive (2000/60/EC) protects available water resources from depletion by setting out all water related impacts framework and promoting sustainable use of water. The abstraction of surface or groundwater sources has to be authorised; however, MS can exempt abstraction where impacts on water are assessed as insignificant. This is aimed at protecting both ground and surface waters and projected areas are enhanced and restored $^{183}$ including analysing human activities and the economics of the river basin and status of water bodies. ${ }^{184}$

In making authorisation decisions competent authorities have to consider impacts from the use and intake of water affecting the river basin areas and should put measures in place to limit such impacts. MS are required to achieve the objectives of the Water Framework Directives by establishing a programme of measures for authorising, controlling the fresh water abstraction and impounding of groundwater. ${ }^{185}$

\subsubsection{Groundwater}

Groundwater is water which is directly in contact with the ground or subsoil and in the saturation zone below the surface of the ground. This includes aquifers which are geological permeable strata that allow large quantities of groundwater to flow or abstract ${ }^{186}$ and body of groundwater is a clearly noticeable volume of groundwater found in an aquifer. ${ }^{187}$

Water Framework Directive 2000/60EC set out to prevent and reduce water pollution making sure water usage is sustainable, to protect the environment ecosystem improvements and floods and drought impact mitigation. This directive was adopted without taking into account the environmental impacts of shale gas which calls for the directive to be reviewed to accommodate shale gas activities. ${ }^{188}$

\footnotetext{
182 See supra footnote 179.

183 Article 4 of Directive 2000/60/EC of the European Parliament and of the Council of 23 October 2000 establishing a framework for Community action in the field of water policy.

184 Article 5 of 2000/60/EC Water Framework Directive.

185 Ibid Articles 4 and 5.

186 Ibid Article 2.11.

187 Ibid Article 2.12.

188 Directorate General for Internal Polices, Workshop on shale gas in the EU: its impact on the environment and the energy policy, from the perspective of petitions received 2012, European Parliament, Brussels.
} 
The IED addresses the risks of leakages through steel and cement constructed well bore risking environmental impact as happened in Germany in 2007 when wastewater pipes leaked contaminating groundwater sources with mercury and benzene. ${ }^{189}$ The IED permits and a management plan is required under the Mining Waste Directive (2006/21/EC). There are also technical standards set up in the oil and gas industry which has to be followed in shale gas activities too, namely ISO 10426-1 which covers well cementing, ISO10405 for casings and ISO 11961 for Drill pipes. ${ }^{190}$

The Recommendations are that there should be a minimum distance kept between water protection and residential areas from the authorised operational areas. A minimum vertical separation risk assessment should be done between the groundwater and areas to be fractured by maintaining minimum limitations of depth. ${ }^{191}$ These distances are not defined in the recommendation leaving it out for the MS to do their own interpretation without clear uniform rules applicable across the EU resulting in MS coming up with different minimum numbers from each other. $^{192}$

A study carried out in September 2014 shows that people who leave in a distance of $1 \mathrm{~km}$ away from the wells are at risk of developing skin and upper respiratory problems than those who leave $2 \mathrm{~km}$ further away. ${ }^{193}$ There is no any scientific evidence so far to conclude that safety of groundwater will be guaranteed by any limitations, but studies confirm that the drilling depth has nothing to do with groundwater contamination ${ }^{194}$ but ageing, corrosion and poor cementing and earth tremors have been suggested to be risks almost unavoidable. ${ }^{195}$

Despite the fact that there is no scientific evidence to the effect that depth limitations are linked to groundwater contamination, some states have introduced depth limitations. The UK February, 2015 Infrastructure bill states that fracking has to take place in not less than $1200 \mathrm{~m}$ away from the groundwater source, except where consent is sort from the Secretary of State. These measurements are taken from the surface putting the reserves at risk because they may be found at different depth and the 1200 limit might be too close in certain areas. ${ }^{196}$

The UK has not yet set a buffer zone between residential areas and oil and gas development areas which are

\footnotetext{
189 See supra footnote 179.

190 Broomfield (2013).

191 See supra footnote 31 .

192 The Washington Times (2016).

193 Rabinowitz et al. (2012).

194 PSE Healthy Energy (2016).

195 Ingraffea and January (2013).

196 HM Government (1998).
}

determined by local planning authorities and permits have been granted for drilling and testing in a groundwater source protection zone 2 area which is around 300 metres from Greater Manchester's, residential suburbs. ${ }^{197}$

Poland's depth limitations are set at $5000 \mathrm{~m}$ as the distance which exploration drilling can be done without an assessment. $^{198}$ On the 15 February 2015 Poland was warned for breaching EU regulation by excluding EIA ${ }^{199}$ which have now forced the Commission to refer Poland to the European court on the 28 April 2016 for failure to adequately assess exploratory mining drillings. ${ }^{200}$ Poland included in its legislation a buffer zone minimum distance set from homes to fracking activities despite being advised to include in their legislation a $500 \mathrm{~m}$ minimum distance in their legislation. ${ }^{201}$

In German fracking could be done near the groundwater zone and there is no buffer zone between the residential and authorised operational zones and the authorities reiterated that they would not consider all depends on the overall geological circumstances of each targeted area. ${ }^{202}$

The other problem is that stored flowback water containing chemicals needs to be disposed properly without causing environmental impacts. ${ }^{203}$ Water Framework Directive does not allow injection into the ground of flowback water with chemicals. This directive generally provides for the protection and conservation of groundwater but the specific groundwater pollution preventive measures are provided in the Groundwater Directive (2006/ 118/EC).

MS are under obligation to establish monitoring schemes through their competent authorities to prevent pollution of groundwater by limiting imputes of pollutants into groundwater and also to be able to notice any changes in the quality of the groundwater in the early stages. ${ }^{204}$ This directive is indirectly applicable to the hydraulic fracturing impacts except on reasonably unforeseen accidents and natural causes. ${ }^{205}$

The issue with this directive is that different interpretations by MS as to whether HVHF is permitted under the Water Framework Directive 200/60/EC and Groundwater Directive 2006/118/EC and also whether wastewater from

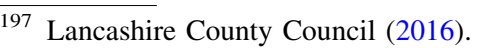

198 International Finance Corporation (2016).

199 Shale Gas International (2015).

200 COMM (2016).

201 See supra footnote 8.

202 FOEE (2015).

203 See supra footnote 38

204 Article 6 and 4 of Directive 2006/118/EC of the European Parliament and of the Council of 12 December 2006 on the protection of groundwater against pollution and deterioration.

205 Article 6 (3) of the Ground Water Directive (2006/118/EC).
} 
hydraulic fracturing can be injected underground for disposal. $^{206}$

\subsubsection{Air quality}

EU Regulation No 525/2013 of the European Parliament and of the Council regulates greenhouse gas emission monitoring and reporting whilst fugitive methane emission is regulated by Directive No 406/2009/EC of the EP and of the Council in an effort to reduce greenhouse gas emissions up to 2010. SG's emission does not only come from diesel motors as explained earlier on, ${ }^{207}$ but the pollution also comes from well heads gas flaring, gas leakages from compressors, evaporation of fracking chemicals from waste ponds during fracking and from underground. ${ }^{208}$

Fracking has been concluded to be responsible to air pollution and the increase in benzene and many other toxic gases from carbohydrates and to be responsible of health issues ranging from eye irritations, sore throats and headaches including high risks of cancer. ${ }^{209}$

Emission from fugitive methane can happen from the processing plants and on transportation and during the production phase contributing to local or regional air pollution with various health impacts. ${ }^{210}$

\subsubsection{Chemicals used in fracking}

The CR 2014 failed to address all the shale gas potential impacts because the EU legislation was already there before the fracking activities stated in the EU. Regulation (EC) No 1907/2006 of the European Parliament and the council on registration, evaluation, authorisation and restriction of chemicals (REACH), and Regulation (EU) 528/2012 of the European Parliament and the Council, meant to promote the availability of chemical and biocidal products are applicable in hydraulic fracturing projects.

A wide variety of chemicals are contained in drilling muds and hydraulic fracturing fluids and registration of chemicals made or brought in the country in large quantities of 1000 tonnes is required as required by Directive 67/548/EEC.

\subsubsection{Chemical registration}

There is no transparency relating to the chemicals used in the hydraulic fracturing in shale gas projects. The EC gave the responsibility of checking transparency on the

\footnotetext{
206 See supra footnote 31.

207 See supra footnote 24.

208 See supra footnote 2.

209 Wolf Eagle Environmental (2009).

210 Boulder County Planning Commissioners (2012).
}

European Chemical Agency (ECHA) by advising MS to check on entities that manufacture, import and use hydraulic fracturing chemical substances to comply with the REACH regulation. This is to make sure that chemicals are declared and registered by adapting the REACH framework. On the other hand, ECHA announced that it was not compulsory for firms to highlight that chemicals are being used in their fracking activities and no action could be taken for failing to comply with the disclosure. ${ }^{211}$ This means that the monitoring is left out for the companies themselves, which is a regulatory weakness. It is therefore difficult for the MS to make sure that operators publicise the chemical substances they use in their fracking as recommended by S15 (a) of 2014 CR if they do not know what chemicals combinations they use.

There has been so far no meaningful data imputing in the ECHA system since it has not been able to discriminate between useful and useless data and recently it has been announced that they are now doing a manual checking of information which could be a mammoth task which means so far the system has been defective. ${ }^{212}$

The International Association of Oil and Gas Producers (IOGP) have their own initiative of voluntarily disclosing chemicals used on wells already fracked. This used by companies that are members of this association such as Cuadrilla for its EU operations, INEOS and Celtique's UK operations and a few others. Still this not enough because it is a voluntary exercise, subscribed by a few companies involved in the fracking business in the EU and their disclosures are for specific geographic areas and only done on projects that have already been fractured after 1 January 2011. ${ }^{213}$ Some of these companies disclose for the whole of their EU operations, whilst some only disclose in certain states as indicated above. This also does not help in preventing chemical damage to the environment by disclosing chemicals that have been used already, which might have caused the damage already.

Disclosures can be viewed as a source of conflict of interests between chemical service companies who want to protect their intellectual property rights of the composition of the chemicals they use in fracking activities and the public's rights to be informed of the composition of chemicals used in fracking activities within their communities. ${ }^{214}$

Section 9 of the CR 2014's recommendation is that operators should monitor their own activities at every stage of the wells' life, shifting the burden of proof from public authorities to operators. Another requirement is to do the

\footnotetext{
211 Flynn (2016).

212 ibid.

213 IAOGP (2016).

214 OPPPW (2014).
} 
testing of well integrity through well design, construction without specifying how frequently these tests should be carried out as they are required even after the well is shut. $^{215}$

\subsubsection{Environmental liability}

Environmental Liability Directive 2004/35/EC is a common framework for liability established by the EU for prevention of imminent threat of environmental damage and to provide remedies for any damages caused. The "polluter pays", principle is the basis of this directive which basically means that a person should be liable for remedial costs where damage is as a result of his fault. This was adopted into the EU law back in the Single European Act 1986, Article 130r (2). ${ }^{216}$ This principle is now covered under Article 191 (2) 2 2TFEU emphasising that prevention and elimination of environmental damage should be paid for by the person who caused the damage. MS are required to take preventive measures as well as restorative action, in cases where the damage has already been done and then claim from the polluter for restoration cost. $^{217}$

It will be reasonable for operators to be obliged to secure financial guarantees to cover such eventualities as recommended by the $\mathrm{CR}$ rather than on a voluntary basis as per directive 204/35/EC.

The Mining Waste Directive puts an obligation on operators to be responsible for monitoring; maintenance and making sure any measures are always in place even after the closure of the shale extraction activities.

The operator is obliged to notify the competent authority within $48 \mathrm{~h}$ of any significant environmental impacts noticed through the waste facility control and monitoring procedures and shall follow any instructions given by the authority in addition to operator's internal emergency plan implementation. $^{218}$

Article 7 of the Environmental Liability Directive provides the remedial measures to be determined and Article 5 provides for preventive actions available for the operator and the competent authorities for necessary measures to be taken to prevent damages. ${ }^{219}$ The Directive also encourages MS to cooperate on preventive or remedial action where the threat of damage may affect more than one MS. $^{220}$

\footnotetext{
$\overline{215}$ See supra footnote 34 .

216 Lindhout and Broek (2014).

217 Article 3 of the Environmental Liability Directive (2004/35/EC).

218 Article 12.4 of the Directive 2006/21/EC.

219 Directive 2004/35/EC of the European Parliament and of the Council of 21 April 2004.

${ }^{220}$ See supra footnote 218 Article 15.
}

Personal restorative measures will be required from the operator, where damage has already occurred. A competent authority has the power to compel operators to the damaged environment as set out in Annex II to the Directive or recover costs of such restoration from the operator. This directive does not expressly refer to shale gas projects and it could have more impact if there is an express reference to shale gas.

\subsubsection{Other directives}

4.5.9.1 The emissions directive (IED) 2010/75/EC This directive was adopted on the 24 November 2010, repealed the Integrated Pollution Prevention and Control (IPPC) as from 7 January 2014. ${ }^{221}$ The directive is aimed at achieving environmental protection at a higher level by integrating pollution control mechanisms on developers who pursue activities in the energy industries that emits into the air, water and land waste management. ${ }^{222}$

Annex 1 of the directive includes industrial installations with a thermal rate of more than $50 \mathrm{MW}$. An installation is a unit which is technical and stationary for the purposes of dealing with any or a number of site activities that could emit and pollute the environment listed in Annex $1 .^{223} \mathrm{~A}$ drilling rig of 5400 horse power (HP) can roughly have an input of only $8 \mathrm{MW}^{224}$ which is far below the threshold of the Annex 1 above limits excluding combustion from single drilling rigs unless counted as multiple installations. ${ }^{225}$

Hydraulic fracturing requires the construction of installations for disposal or recovery of hazardous waste as described in Article 1 (4) of the Directive 91/689/EEC, Council Directive as amended by Directive 2008/98/EC. Hydraulic fracturing process uses a lot of water and various chemicals in propping up shale gas. A threshold of hydraulic fracturing fluid classified as hazardous has been set by the EC decision 2000/532/EC.

An IED permit has to be obtained for the installations for disposing the hazardous substances ${ }^{226}$ and non-hazardous waste material discharged at a rate of more than 50 tonnes per day. ${ }^{227}$ Hazardous waste is material that contains a number of hazardous properties that is oxidising, toxic, flammable, corrosive, irritant and many other characteristics that are capable of generating into other substances hazardous waste material. ${ }^{228}$

\footnotetext{
221 The Commission (2016).

222 Annex 1 Directive (2008/1/EC).

223 Article 2(3).

${ }^{224}$ New York DEC (2011).

225 Annex I of the Directive 2006/12/EC of European Parliament and of the Council of 5 April 2006 on waste.

226 See supra Fig. 1.

227 See Annex II A supra footnote 225.

${ }^{228}$ See Point 2 of supra footnote 170
} 
The IED Directive is applicable to installations on hydraulic fracturing projects that includes shale gas exploitation site as long as these installations meet the waste management criteria stipulated in Annex 1.229

\subsubsection{IED shortfall}

Hydraulic fluids used can be commercially sensitive and its composition may be protected from disclosure of which different chemical compositions can be applied at different sites by different developers. ${ }^{230}$ The non-disclosure commercial protection of the combination of chemicals used in fracking activities makes it difficult to determine how hazard the chemicals used will be. There should be an obligation of obtaining a permit on the whole site which is not provided for in the EU shale gas legislation.

Where a permit under the IED is required, monitoring of emissions to air will be stipulated in the permit and the competent authority is empowered to inspect and monitor compliancy as determined by individual $\mathrm{MS}^{231}$ The uncertainty of HVF technology's characteristics makes it difficult to conclude that the EU legislation in this respect is adequate. ${ }^{232}$

\subsubsection{Noise impact}

A number of Directives are relevant in relation to the controlling of the noise impact some included in the general legislation discussed above, namely the EIA Directive (2011/92/EU, the SIA directive (2001/42/EC, the Noise Directive (2002/49/EC, the outdoor machinery noise directive (2000/14/EC) and the IED Directive (2008/1/EC). Under the EIA Directive, it is not mandatory to take measures on noise impact during drilling; however, it is the responsibility of the MS to make sure the relevant authority is furnished with the potential environmental impacts such as noise especially in hydrocarbons hydraulic fracturing operations.

\subsubsection{The outdoor machinery noise}

Much of the equipment used for HVHF has to meet certain defined noise levels before it is used on site. HVHF drilling equipment is not on the list of equipment covered in the Directive 2000/14/EC and compressors over $350 \mathrm{kw}$ are also excluded. This is a shortfall on the part of the EU legislation indicates that there are no noise limits from

\footnotetext{
$\overline{229}$ See supra footnote 190.

230 Reins (2011).

${ }^{231}$ See Article 9 (5) of Supra footnote 223.

${ }^{232}$ See supra footnote 230.
}

drilling activities for shale gas extraction and no mandatory steps to mitigate noise are given. ${ }^{233}$

\section{Conclusions}

This article revealed a number of issues surround the EU's, "soft law", regulatory approach for shale gas activities including that it is a non-binding and a non-coherent recommendation. It would appear some of the HVHF risks at the surface appear to be prima facie addressed when examining some of the above provisions, but, however, there is a clear lack of coherent, comprehensive approach regarding SIA, EIA, baseline monitoring and reporting requirements, well integrity and chemicals disclosure. ${ }^{234}$

The CR does not have the necessary power to compel EU MS to put efforts in setting up minimum standards in regulating shale gas activities and comprehend the need and importance of carrying out SIA and be able to assess the cumulative effects of shale gas activities. There is too much reliance in mitigating shale gas impacts by applying the conventional oil and gas industry's best practice and self-monitoring.

Member states are cherry picking what they want to apply on the recommendations and not using it as a basis of making their strong regulation for fracking. Some member states made it clear that they cannot afford or are illequipped to deal with certain fracking challenges. There is lack of monitoring capacity among MS for different reason including conflicts of interest and corrupt practices.

The public concerned with fracking activities are consulted only as a formality and not with the expectation of a constructive feedback that can be used in a decision making process of which they are either given short period to review complicated documents. Some states are just transposing the Recommendations in their regulatory framework just to convince the EU Commission that they are complying with the EU law and not taking seriously the impacts of the fracking.

The development of shale gas exploration and production is going to remain in the interest of many EU MS and the industry for some time. The legal, regulatory, policies and the natural settings will determine the ability of individual states to realise self-sufficiency from their local shale gas resources as well as the ability of the operators to economically manage the projects viably and make profits.

Projects have failed to take off in some MS, developers withdrawing after being licensed as witnessed in Poland where five companies, including ConocoPhillips and Exxon Mobil and three others have withdrew from carrying

\footnotetext{
233 ibid.

${ }^{234}$ See supra footnote 26.
} 
out shale gas activities to the great disappointment to the Polish government. ${ }^{235}$ Therefore, shale gas prices and speed of production volumes will be not good enough as compared to that of the USA and the costs of production are estimated to go up three times per unit of gas as compared to that of the USA. ${ }^{236}$ There should not be too much excitement about the development of shale gas in the EU because it is not going to be business as usual.

The regulatory framework is failing to address the environmental concerns raised from shale gas activities which are not yet fully understood coupled by lack of regulatory confidence and public distrust. There have been a series of reports, comments, directive amendments and recommendations coming up with different ideas as to how shale gas legislation can be improved but so far there is lack of new smart rules which effectively addresses the key shale gas development concerns. The Commission, however, decided to take the softest regulatory policy which is cheaper to implement compared to other options available which has so far proved to be incapable of protecting the health and the environment from the impacts of SG activities.

\subsection{Recommendations}

The EU should make sure those high standards of transparency on project that may have cross-border impacts are implemented and strictly monitored SEA and EIA to be carried across borders whenever a trans-boundary project is carried out even if thresholds are different in both states. ${ }^{237}$

There should be specific legal requirements of monitoring shale gas projects fracturing activities in all MS which so far only two EU countries, the UK and Denmark, put such provisions in their legislation. ${ }^{238}$

Impacts from shale gas projects are localised in nature which makes local level regimes to be more relevant in determining the economic attractiveness of shale gas projects. There should be an adjoined up strategic thinking and cooperation between stakeholders and remove the fragmentation of regulatory approaches to develop public trust and confidence with the potential investors.

There are challenging compliancy monitoring and enforcement actions which should be prioritised in the EU. There are also practical challenges on the overlapping nature of the shale gas developing stages which complicates the interaction of all stakeholders throughout the

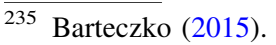

236 Parliamentary Copyright (2012).

237 Case C-205/08 Umweltanwalt von Kärnten v Kärntner Landesregierung [2010] Env.LR 15.

${ }^{238}$ See supra footnote 8.
}

development lifecycle. At this infant stage of the shale gas industry development, environmental and social regulatory risks will put pressure on operators as policy makers try to correct the deficiencies in the current legislation in shale gas practices and trying to achieve their nations' social needs.

The environmental impacts can be devastating in the communities where projects involving fracking are located therefore individual states should take more precautionary measures to safeguard their environment and the health of their citizens who may be affected with impact of the effects of shale gas exploration and production.

It should be the prerogative of MS to monitor all shale gas activities they authorise in their states than to delegate monitoring to the developers themselves by establishing national environmental inspectors who monitor the activities of operators on projects with potential impacts to the environment such as the shale gas extraction and production. Self-monitoring and self-regulation have proved to be very in effective and pushed the establishment of a social licence to operate much further.

Application of these regulations also comes at a price and some MS are already financially struggling and cannot afford to finance the management process of authorisations, permits and monitoring as required and then. This all points out to the conclusion that regulation of shale gas activities impacts cannot be said to be fit for purpose in the $\mathrm{EU}$ at the moment.

Open Access This article is distributed under the terms of the Creative Commons Attribution 4.0 International License (http://crea tivecommons.org/licenses/by/4.0/), which permits unrestricted use, distribution, and reproduction in any medium, provided you give appropriate credit to the original author(s) and the source, provide a link to the Creative Commons license, and indicate if changes were made.

\section{References}

Aitken G, Burley H et al. (2012) Shale gas, Unconventional and unwanted': the case against shale gas, extractive industries: blessing or curse? Friends of the Earth (FOE). https://www. foeeurope.org/sites/default/files/publications/foee_shale_gas_ unconventional_unwanted_0.pdf. Accessed 30 March 2016

Aldhous P (2012) Special Report "Drilling into the Unknown". New Scientist, Issue 2849 , pp. 8-10 .https://www.newscientist.com/ article/mg21328493-800-fracking-health-risks-drilling-into-theunknown/. Accessed 22 April 2016

Altmann M et al. (2011) LBST.de impacts of shale gas and shale oil extraction on the environment and on human health-executive presentation-Oct-11. http://www.europarl.europa.eu/meetdocs/ 2009_2014/documents/envi/dv/shalegas_pe464425_exec-presen tation_/shalegas_pe464425_exec-presentation_en.pdf. Accessed on 24 March 2016

Armstrong C (2013) Against Permanent Sovereignty over Natural Resources. Politics, Philosophy and Economics .http://ssrn.com/ abstract $=2350884$. Accessed 28 Oct 2015 
Associated Press (2015) Fracking wastewater spills increase. http:// www.postindependent.com/news/18093706-113/fracking-waste water-spills-increase. Accessed 29 April 2016

Banks K, Reporter (2001) MP demands answers on why waste water from fracking was dumped into the Manchester ship canal. http:// www.messengernewspapers.co.uk/news/10971603.MP_ demands_answers_on_why_waste_water_from_fracking_was_ dumped_into_the_Manchester_Ship_Canal/. Accessed 27 Aril 2016

Barteczko A (2015) Markets, UPDATE 1. Conoco the last global oil firm to quit Polish shale gas. Warsaw. Reuter http://www. Reuters.com/article/Conoco-Poland-Shalegas-idus15noyr2R3201 50605. Accessed 11 April 2016

Ballesteros M (2009) Environmental Law Network International EU Enforcement Policy of Community Environmental law as presented in the Commission Communication on implementing European Community Environmental law. http://www.clien tearth.org/reports/general-eu-elni-enforcement-2009-Ballesteros2009-10-20-finalversion.pdf. Accessed 30 Aug 2016

Bamberger M, Oswald ER (2012) Impacts of gas drilling on human and animal health new solutions 22(1):51-77. Baywood Publishing Co., Inc. http://psehealthyenergy.org/data/Bamberger_ Oswald_NS22_in_press.pdf. Accessed 01 Sep 2016

Bamberger M, Oswald ER (2015) Long-term impacts of unconventional drilling operations on human and animal health. J Environ Sci Health 50:447-459

Benidickson J, Boer B et al (2011) Environmental law and sustainability after Rio. Edward Elga Publishing, UK, p 20

Boulder County Planning Commissioners (2012) http://www.boulder county.org/doc/landuse/oilgaspubliccomments20121030.pdf. Accessed 03 May 2016

Boutilier RG (2014) Frequently asked questions about the social licence to operate. Impact Assess Project Apprais 32(4):263-272

Broomfield M (2013) Support to the identification of potential risks for the environment and human health arising from hydrocarbons operations involving hydraulic fracturing in Europe. ED57281Issue Number 17c, 2013

Brown D, Weinberger B, Lewis C, Bonaparte H (2014) Understanding exposure from natural gas drilling puts current air standards to the test. Rev Environ Health. doi:10.1515/reveh-2014-0002

Brown DR, Lewis C, Weinberger BI (2015) Human exposure to unconventional natural gas development: a public health demonstration of periodic high exposure to chemical mixtures in ambient air. J Environ Sci Health, Part A 50:460-472

Bubsby J (2016) Fracking wastewater. http://www.after-oil.co.uk/ fracking_wastewater.htm. Accessed 27 April 2016

Bugarski S, Maulet N (2013) Shale gas in Europe SBU. https://www. stratley.com/fileadmin/pdfs/130920_Shale_Gas_in_Europe_SBU. pdf. Accessed 30 April 2016

Bundesanstalt für Geowissenschaften und Rohstoffe (BGR) [Federal Institute for Geosciences and Natural Resources]. Energy study. Reserves, resources and availability of energy resources 2013 (2014) http://www.bgr.bund.de/EN/Themen/Energie/Downloads/ energiestudie_2013_en.pdf;jsessionid=54D12474B6F373807F3C 72873AE96593.1_cid284?_blob=publicationFile\&v=2. Accessed 1 May 2016

Charlez P (2015) An introduction to shale oil and gas Shale drilling site in Pennsylvania -photo Helge Hansen -Statoil. http://www.iogp. org/Portals/0/Downloads/An\%20introduction\%20to\%20shale\% 20oil\%20and\%20gas-Jul2015-1.pdf?ver=2015-12-15-162610167. Accessed 28 Dec 2015

Clark P, Bounds A (2015) Ministers freed to intervene in fast-track fracking drive. Councils face being overruled if decisions on drilling applications are slow or confused, 13 August 2015. The Financial Times https://next.ft.com/content/a346b038-411411e5-b98b-87c7270955cf. Accessed 15 April 2016
COMM (2012) The IPPC directive-environment-European commission. http://ec.europa.eu/environment/archives/air/stationary/ ippc/ippc_revision.htm. Accessed 28 April 2016

COMM (2016) Environmental impact assessment: commission refers POLAND to the court of justice of the EU over inadequate assessment of exploratory mining drillings. http://europa.eu/ rapid/press-release_IP-16-1454_en.htm. Accessed 29 April 2016

Corporate Dispute Magazine (2014) Disputes in the energy sector financier Worldwide October 2014. http://www.navigant.com/ $\sim /$ media/WWW/Site/Insights/Disputes\%20Investigations/Dis putes $\% 20$ in $\% 20$ the $\% 20$ Energy $\% 20$ Sector $\% 20$-\%20Financier $\%$ 20Worlwide\%20-\%20October\%202014.ashx. Accessed 2 May 2016

Critchley P (1995) The European Union and the Principle of Subsidiarity. Industry and Europe vol I. http://mmu.academia. edu/PeterCritchley/Books. Accessed on 16 March 2016

Dinan D (1999) Ever Closer Union. "An introduction to European Integration'. Macmillan Ltd., New York, p 410

Director General for Internal Policies, Workshop on shale gas in the EU: Its impact on the environment and the energy policy, from the perspective of petitions received 2012, European Parliament, Brussels. http://www.europarl.europa.eu/RegData/etudes/work shop/join/2012/462486/IPOL-PETI_AT(2012)462486_EN.pdf. Accessed on 30 March 2016

Directorate-General for Communication (2016) Flash Eurobarometer 420: attitudes of citizens towards shale gas in selected European regions .http://open-data.europa.eu/en/data/dataset/S2066_420_ ENG. Accessed on 05 April 2016

Dobra LJ, Newman D (2014) The case for private ownership of mineral rights. http://www.miningfacts.org/Blog/Mining-News/ The-Case-for-Private-Ownership-of-Mineral-Rights/. Accessed 09 April 2016

Duncan Brack (2001) International Environmental Disputes: international forums for non-compliance and dispute settlement in environment-related cases. https://www.ippc.int/static/media/ files/publications/en/1182350929558_Noncompliance_Brack.pdf. Accessed 2 May 2016

Dupont C et al (2013) Regulatory provisions governing key aspects of unconventional gas extraction in selected member states final report. http://ec.europa.eu/environment/integration/energy/pdf/ Final\%20Report\%2024072013.pdf. Accessed 16 April 2016

EC (2015) DG Environment, Technical support for assessing the need for a risk management framework for unconventional gas extraction. AMEC Final Report http://ec.europa.eu/environ ment/integration/energy/pdf/study_management_ei.pd. Accessed on 22 April 2016

EIA (2012) What is shale gas and why is it important, 05 December 2012, United States. http://energy.gov/sites/prod/files/2013/04/ f0/why_is_shale_gas_important.pdf. Accessed 19 April 2016

EIA (2013) Technically recoverable shale oil and shale gas resources: an assessment of 137 shale formations in 41 countries outside the United June 2013 States. https://www.eia.gov/analysis/studies/ worldshalegas/archive/2013/pdf/fullreport_2013.pdf. Accessed 9 March 2016

EIA (2015) The Annual Energy Outlook 2015 (AEO2015 U.S. Energy Information Administration https://www.eia.gov/fore casts/aeo/pdf/0383(2015).pdf. Accessed 29 Dec 2015

EIA Natural Gas from Shale (2013) Questions and answers. http:// energy.gov/sites/prod/files/2013/04/f0/why_is_shale_gas_impor tant.pdf. Accessed 19 April 2016

Environmental and social performance standards and guidance notes. http://www.ifc.org/performancestandards. Accessed 27 April 2016

EPA (2011) United States of America, Lessons Learned from Natural Gas STAR partners, reduced emissions completions for hydraulically fractured natural gas wells. http://www3.epa.gov/gasstar/ 
documents/reduced_emissions_completions.pdf. Accessed 01 Jan 2016

Europa (2016) European Institutions http://eur-lex.europa.eu/sum mary/glossary/eu_institutions.html. Accessed no 24 April 2016

European Commission (2012) Final Report on Unconventional Gas in Europe in the framework of the multiple framework service contract for legal assistance. TREN/R1/350-2008 lot 1. https:// ec.europa.eu/energy/sites/ener/files/documents/2012_unconven tional_gas_in_europe.pdf. Accessed on 15 April 2016

European Commission (2016) Impact Assessment, Exploration and production of hydrocarbons (such as shale gas) using high volume hydraulic fracturing in the EU, COM 201423 Final Part 1/4. http://eur-lex.europa.eu/resource.html?uri=cellar:a46647dd843b-11e3-9b7d-01aa75ed71a1.0001.01/DOC_1\&format=PDF. Accessed on 06 March 2016

European Commission DG Environment (2012) Support to the identification of potential risks for the environment and human health arising from hydrocarbons operations involving hydraulic fracturing in Europe. AEA/R/ED57281 Issue Number 17c http:// ec.europa.eu/environment/integration/energy/pdf/fracking\%20study. pdf. Accessed on 18 March 2016

European Commission DG Environment Technical Support for the Risk Management of Unconventional Hydrocarbon Extraction Final Report (2015). Amec http://ec.europa.eu/environment/ integration/energy/pdf/study_management_ei.pdf. Accessed on 22 April 2016

European Commission Environment (2016) Co-operation with Judges. http://ec.europa.eu/environment/legal/law/judges.htm. Accessed on 06 April 2016

European Commission: DG Climate Action (2012) Climate impact of potential shale gas production in the EU. AEA http://ec.europa. eu/clima/policies/eccp/docs/120815_final_report_en.pdf. Accessed on 16 Feb 2016

European Parliament 2011/2308(INI) (2012) On the environmental impacts of shale gas and shale oil extraction activities, European Parliament, 21 November 2012 .http://www.europarl.europa.eu/ document/activities/cont/201312/20131205ATT75545/2013120 5ATT75545EN.pdf. Accessed on 29 Dec 2015

European Parliament (2012) Communication on Implementing EU environment legislation-Questions and Answers MEMO/12/ 159. http://europa.eu/rapid/press-release_MEMO-12-159_en. $\mathrm{htm}$ ?locale=en. Accessed on 27 March 2016

European Parliament (2016) Decision No 1386/2013/EU of The European Parliament and the Council, of 20 November 2013, on a General Union Environment Action Programme to 2020. Living well, within the limits of our planet. http://eur-lex.europa. eu/legal-content/EN/TXT/?uri=CELEX:32013D1386. Accessed on 04 April 2016

European Parliament, Compliancy Promotion (2016) Communication on improving the delivery of benefits from EU environment measures: building confidence through better knowledge and responsiveness, 7 March 2012. http://ec.europa.eu/environment/ aarhus/pdf/session_gw11.pdf. Accessed on 27 March 2016

European Union, Countries (2016) Member countries of the EU. http://europa.eu/about-eu/countries/index_en.htm. Accessed on 04 April 2016

Exxon Mobil (2014) Unconventional resources developmentmanaging the risks. http://cdn.exxonmobil.com/ /media/glo bal/files/energy-and-environment/unconventional_resources_ development_risk_management_report.pdf. Accessed 20 Dec 2015

EY (2013) Shale gas in Europe: revolution or evolution. http://www. ey.com/gl/en/industries/oil—gas/shale-gas-in-europe-revolutionor-evolution. Accessed 09 March 2016

Fleming R (2012) Shale Gas-a Comparison of European Moratoria. European Energy Environ Law Review 22(12):12-32. https://
www.kluwerlawonline.com/abstract.php?area=Journals\&id=EE LR2013002. Accessed 19 April 2016

Fleming R (2015) Towards reasonable European shale gas regulationthe European Commission's 214 recommendation Communication on Shale Gas Extraction. Offshore Europe Conference and Exhibition, (8-11 September 2015) Society of Petroleum Engineers (SPE), Aberdeen, Scotland

Flynn V (2016) Disclose fracking chemicals. EU tells firms, 19 Mar 2015 Europe's environmental news and information service (ENDS Europe). http://www.endseurope.com/article/40089/dis close-fracking-chemicals-eu-tells-firms. Accessed 14 April 2016

FOEE (2015) Fracking business as usual report, 081015. http://www. foeeurope.org/sites/default/files/shale_gas/2015/foee_-_frack ing_business_as_usual_report_081015.pdf. Accessed 12 April 2016

France-Presse A (2013) Seven charged with corruption over Shale gas in Poland. http://www.industryweek.com/energy-management/ seven-charged-corruption-over-shale-gas-poland. Accessed 29 April 2016

Green AC, Styles P, Baptie JB (2012) Induced seismicity mitigation report, shale gas fracturing review and recommendations for induced seismic mitigation. Preese Hall. https://www.gov.uk/ government/uploads/system/uploads/attachment_data/file/15745/ 5075-preese-hall-shale-gas-fracturing-review.pdf. Accessed 01 Jan 2016

Guidance note on the application of Directive 85/337/EEC to projects related to the exploration and exploitation of unconventional hydrocarbon. http://ec.europa.eu/environment/integration/ energy/pdf/guidance_note.pdf. Accessed on 05 April 2016

Hámor T et al (2010) Review of EU community legislation European community law relevant to aggregates. SARMa http://www. sarmaproject.eu/uploads/media/EULawPreSynthReportAug3.pdf. Accessed 04 April 2016

Hawkins J (2015) Fracking: Minding the gaps. Univ Bristol UK Environ Law Rev 17(1):8-21. http://elj.sagepub.com/content/17/ 1/8.full.pdf. Accessed 05 Sep 2016

Henry T, Galbraith K (2016) Wastewater disposal wells proliferate along with Fracking U.S. http://www.nytimes.com/2013/03/29/ us/wastewater-disposal-wells-proliferate-along-with-fracking.html?_ $\mathrm{r}=0$. Accessed 2 May 2016

Horia Maican O (2013) Legal regime of shale gas extraction. Academy of Economic Studies 2 III(6). http://www.scientificpa pers.org/wp-content/files/1420_Maican-LEGAL_REGIME_OF_ SHALE_GAS_EXTRACTION.pdf. Accessed 16 Aug 2016

HM Government (1998) Ukdsi 9780111137932 en. http://www. legislation.gov.uk/ukdsi/2015/9780111137932/pdfs/ukdsi_9780 111137932_en.pdf. Accessed 28 April 2016

HSE (2016) Board Paper-Emerging Energy Technologies-Update on Developments with Unconventional Gas. http://www.hse.gov. uk/aboutus/meetings/hseboard/2013/250913/psepb1391.pdf. Accessed 06 April 2016

http://www.climatechange2013.org/f

http://www.worldenergyoutlook.org/media/weowebsite/2012/golden rules/weo2012_goldenrulesreport.pdf

IAOGP (2016) Find a well-hydraulic fracturing (also known as fracking) fluid and additive transparency service. http://www. ngsfacts.org/findawell/. Accessed 14 April 2016

IEA (2012) World Energy Outlook, Golden Rules for a Golden Age of Gas, World Energy Outlook Special Report on Unconventional Gas. http://www.worldenergyoutlook.org/media/weoweb site/2012/goldenrules/weo2012_goldenrulesreport.pdf. Accessed on 27 March 2016

Ingraffea RA, January EP (2013) Fluid migration mechanisms due to faulty welding design and or construction: an overview and recent experiences in the Pennsylvania Marcellus Play. http:// psehealthyenergy.org/data/PSE_Cement_Failure_Causes_and_ 
Rate_Analaysis_Jan_2013_Ingraffea1.pdf. Accessed 28 April 2016

International Association of Oil and Gas Producers (2014) http:// www.ngsfacts.org/files/9014/0076/6591/v2_Shale_FAQs_1.2_ high.pdf. Accessed on 24 March 2016

International Finance Corporation (2016) Environmental and social performance standards and guidance notes. http://www.ifc.org/ performancestandards. Accessed 27 April 2016

Ittershagen $\mathrm{M}$ et al. (2014) Presse-und Öffentlichkeits- arbeit': Fracking jetzt regulieren'. http://www.umweltbundesamt.de/ sites/default/files/medien/479/dokumente/pi-2014-33_fracking jetzt_regulieren.pdf. Accessed 2 May 2016

Lancashire County Council (2014) Extension of consultation period for shale gas sites. http://www3.lancashire.gov.uk/corporate/ news/press_releases/y/m/release.asp?id=201407\&r=PR14/0317. Accessed 15 April 2016

Lancashire County Council (2016) Planning application. http:// planningregister.lancashire.gov.uk/PlanAppDisp.aspx?recno=6591. Accessed 28 April 2016

Lindhout PE, Broek BVD (2014) The polluter pays principle: guidelines for cost recovery and burden sharing in the case law of the European court of justice' SSRN. http://papers.ssrn. com/sol3/Papers.cfm?abstract_id=2436984. Accessed 28 April 2016

Luscombe D, Corden C (2015) Technical support for the risk management of unconventional hydrocarbon extraction final report. http://ec.europa.eu/environment/integration/energy/pdf/ study_management_ei.pdf. Accessed on 22 April 2016

Mason R (2014) Environmental Agency: New Environment Agency chairman has fracking link. The Guardian http://www.theguar dian.com/environment/2014/jul/22/environment-agency-chairmanfracking-links. Accessed 14 April 2016

McArdle H, Gilhooly C (2014) Shale regulation in Europe-new developments and their impact in the UK. Part 1, Shale World .http://www.shale-world.com/2014/03/19/download-shale-regula tion-europe-new-developments-impact-uk-part-1. Accessed 5 April 2016

Moffat K, Zhang A (2014) The paths to social licence to operate: an integrative model explaining community acceptance of mining. Resourc Policy 39(1):61-70

Meiners G, Denneborg M et al (2013) Environmental impacts of fracking related to exploration and exploitation of unconventional natural gas deposits: risk assessment, recommendations for action and evaluation of relevant existing legal provisions and administrative structures. UWETBUNDSAT https://www. umweltbundesamt.de/sites/default/files/medien/378/publikationen/ texte_83_2013_environmental_impacts_of_fracking.pdf. Accessed on 15 April 2016

Moore V, Beresford A, Gove B (2014) Hydraulic fracturing for shale gas in the UK Examining the evidence for potential environmental impacts. RSPB $<$ https://rspb.org.uk/fracking. Accessed 29 Dec 2015

Nagan WP, Hammer C (2004) The changing character of sovereignty in international law and international relations. University of Florida. https://milestonesforlife.com/thetaxistand/sov.pdf. Accessed 09 Oct 2015

Natural Gas Europe (2012) Update: Poland shale gas licensing scandal. Corruption scandal in Poland. http://www.naturalgaseu rope.com/tusk-blames-poland-shale-gas-corruption. Accessed 19 April 2016

New York (2011) Potential environmental impacts (DEC 2011 PR) pp 6-100. http://www.dec.ny.gov/docs/materials_minerals_pdf/ rdsgeisch6a0911.pdf. Accessed 10 March 2016

OECD (2006) DAC guidelines and reference series: applying strategic environmental assessment: good practice guidance for development co-operation. http://www.oecd.org/environment/ environment-development/37353858.pdf. Accessed on 15 April 2016

OPPPW (2014) Fracturing fluid composition-OPPPW Poland. http://www.opppw.pl/en/fracturing_fluid_composition/23. Accessed 29 April 2016

Parliamentary Copyright (2012) The impact of Shale gas on energy markets. http://www.publications.parliament.uk/pa/cm201213/ cmselect/cmenergy/writev/isg/m05.htm. Accessed 18 April 2016

Pearson I, Zeniewski P, Gracceva F, Zastera P (2012) Unconventional gas: potential energy market impacts in the European Union. European Commission Joint Research Centre, p 7

Peltier L et al (2016) Pennsylvania Fracking water contamination much higher than reported' (Energy, 4 February 2016). http:// ecowatch.com/2016/02/04/pa-fracking-water-contamination/. Accessed 2 May 2016

Petroleum Review (2015) UK Fracking Off once more. Energy Institute https://knowledge.energyinst.org/Energy-Matrix/pro duct?product=94149. Accessed 15 April 2016

Petroleum and Natural Gas Industries (2006) Care and use of casing and tubing (ISO 10405:2006). http://www.iso.org/iso/iso_catalo gue/catalogue_tc/catalogue_detail.htm?csnumber=55304. Accessed on 24 Aril 2016

Petroleum and Natural Gas Industries (2009) Cements and materials for well cementing_-part 1: Specification (ISO 10426-1:2009). http://www.iso.org/iso/iso_catalogue/catalogue_tc/catalogue_ detail.htm?csnumber=55304. Accessed on 24 Aril 2016

Petroleum and Natural Gas Industries (2011) Drilling fluidsprocessing equipment evaluation (ISO 13501:2011). http:// www.iso.org/iso/iso_catalogue/catalogue_tc/catalogue_detail.htm? csnumber $=55304$. Accessed on 24 April 2016

Potocnik J (2012) Transmission Note on the EU environmental legal framework applicable to shale gas projects' Ares. http://ec. europa.eu/environment/integration/energy/pdf/legal_assessment. pdf. Accessed on 5 April 2016

PSE Healthy Energy (2016) PSE healthy energy. http://psehealthye nergy.org/site/view/1233. Accessed 28 April 2016

Rabinowitz PM et al (2012) EHP-proximity to natural gas wells and reported health status: Results of a household survey in Washington county, Pennsylvania. http://ehp.niehs.nih.gov/ 1307732. Accessed 28 April 2016

Reins L (2011) The shale gas extraction process and its impacts on Water Resources. Rev Euro Commun Int Environ Law 20:301

Rowell A (2014) Environment agency investing pension fund in industries it regulates is "clear conflict of interest. The Independent-Green Living. http://www.independent.co.uk/environ ment/green-living/environment-agency-investing-pension-fundin-industries-it-regulates-is-clear-conflict-ofinterest-9946597.html. Accessed 29 April 2016

Royal Society and The Royal Academy of Engineering (2012) Shale gas extraction in the UK: a review of hydraulic fracturing Issued: June 2012 DES2597. The 2012 http://www.raeng.org.uk/publica tions/reports/shale-gas-extraction-in-the-uk. Accessed 27 Nov 2015

Scheuer S (2016) EU Environmental Policy Handbook: A critical analysis of EU Environmental Legislation Making it accessible to environmentalists and decision makers. European Environmental Bureau (EEB). www.wems/download/2004-2005/EEB Book.pdfcf.eu/c. Accessed on 04 May 2016

Section 3 of the Petroleum Act 1988 UK

Shaw NM (2008) International Law, 6th edn. Cambridge University Press, Cambridge, p 487

Shale Gas International, Unintentional Gas and Oil News (2015) Polish fracking law in breach of EU directive-European commission says, 27 February 2015). http://www.shalegas. international/2015/02/27/polish-fracking-law-in-breach-of-eudirective-european-commission-says/. Accessed 28 April 2016 
Simons Z (2014) Landmark Chambers 2014. Barristers chambers London. http://www.landmarkchambers.co.uk/userfiles/.../ZS_ Fracking_and_EIA.pdf. Accessed 18 April 2016

Sreeramula P (2013) Shale gas in Europe: Revolution or evolution?. http://www.ey.com/gl/en/industries/oil—gas/shale-gas-in-europerevolution-or-evolution. Accessed 02 Jan 2016

Supplemental generic environmental impact statement on the oil, gas and solution mining regulatory program well permit issuance for horizontal drilling and high-volume hydraulic fracturing to develop the Marcellus Shale and other Low-Permeability gas Rese (2011). http://www.dec.ny.gov/data/dmn/rdsgeisfull0911. pdf. Accessed 27 April 2016

The Commission (2016) IPPC Directive, towards an improved policy and industrial policy: Commission takes steps to cut industrial emissions further 2007. http://ec.europa.eu/environment/ archives/air/stationary/ippc/ippc_revision.htm. Accessed on 30 March 2016

The European Commission (2014) Exploration and production of hydrocarbons (such as shale gas) using high volume hydraulic fracturing in the EU COM (2014) 23 final. http://eur-lex.europa. eu/legal-content/EN/TXT/?uri=CELEX:52014SC0022. Accessed on 06 March 2016

The European Commission (2014) Interpretation of definitions of project categories of Annex 1 and II of the EIA Directive (2015). http://europa.eu/pol/index_en.htm. Accessed on 04 April 2016

The European Commission (2015) Interpretation of definitions of project categories of Annex 1 and II of the EIA Directive. Publications Office http://ec.europa.eu/environment/eia/pdf/ cover_2015_en.pdf

The European Council (2014) Qualified majority: a new rule from 1 November 2014. http://www.consilium.europa.eu/en/council-eu/ voting-system/qualified-majority/. Accessed on 11 April 2016

The European Union, Environment (2014) A healthy and Sustainable environment for present and future generations. http://europa.eu/ pol/index_en.htm. Accessed on 04 April 2016

The European Union Explained (2014) Environment, a healthy and Sustainable environment for present and future generations. http://europa.eu/pol/index_en.htm. Accessed 04 April 2016
The United Nations, Human Rights, General Assembly resolution 1803 (XVII) of 14 December 1962. Permanent sovereignty over natural resources. http://www.ohchr.org/EN/ProfessionalInterest/ Pages/NaturalResources.aspx. Accessed 09 April 2016

The Washington Times (2016) Task force likely won't suggest bigger buffer zone for wells. http://www.washingtontimes.com/news/ 2015/feb/3/drilling-panel-tries-to-find-consensus-on-oil-gas. Accessed 28 April 2016

Thomson I, Boutilier GR (2011) Modelling and measuring the social license to operate: fruits of a dialogue between theory and practice

UNECE (1998) Public participation in decision making and access to justice in environmental matters (the Aarhus Convention). http:// www.unece.org/fileadmin/DAM/env/pp/documents/cep43e.pdf. Accessed on 26 March 2016

UNECE (2003) Protocol on Strategic Environmental Assessment (SEA). https://www.unece.org/fileadmin/DAM/env/eia/docu ments/legaltexts/protocolenglish.pdf. Accessed on 15 April 2016

Van Hoecke M (2011) Methodologies for legal research. Which kind of method for what kind of discipline. Methodologies of Legal Research European Academy of Legal Theory Series, vol 9. Hart Publishing, London

Vopel C (2012) EU environmental framework applicable to shale gas practices: Impact of Shale Gas and Shale Oil Extraction on the Environment and on Human Health. http://www.europarl. europa.eu/document/activities/cont/201312/20131205ATT75545 /20131205ATT75545EN.pdf. Accessed on 29 Dec 2015

Wang $Q$ et al (2014) Natural gas from shale formation. The revolution, evidence and challenges of shale gas revolution in United States. Renew Sustain Energy Rev 30:1-28

Wolf Eagle Environmental (2009) Town of DISH, Texas ambient air monitoring analysis final report September 15, 2009. http:// townofdish.com/objects/DISH_-_final_report_revised.pdf. Accessed 29 March 2016 